\title{
Optical Reporters for the Conformation of $\alpha$-Synuclein Reveal a Specific Interaction with Mitochondria
}

\author{
Ken Nakamura, ${ }^{1}$ Venu M. Nemani, ${ }^{1}$ Erika K. Wallender, ${ }^{1}$ Katrin Kaehlcke, ${ }^{2}$ Melanie Ott, ${ }^{2}$ and Robert H. Edwards ${ }^{1}$ \\ ${ }^{1}$ Graduate Programs in Neuroscience and Cell Biology, Departments of Neurology and Physiology, and ${ }^{2}$ Gladstone Institute of Immunology, University of \\ California at San Francisco, San Francisco, California 94143
}

\begin{abstract}
The aggregation of abnormally folded proteins is a defining feature of neurodegenerative disease, but it has not previously been possible to assess the conformation of these proteins in a physiologically relevant context, before they form morphologically recognizable aggregates. We now describe FRET-based reporters for the conformation of $\alpha$-synuclein, a protein central to the pathogenesis of Parkinson's disease (PD). Characterization in vitro shows that $\alpha$-synuclein adopts a relatively "closed" conformation in solution that converts to "open" on membrane binding. In living cells, the closed conformation predominates. In neurons, however, cell bodies contain a much larger proportion of the open conformation than synaptic boutons. To account for these differences, we also used the reporters to characterize the interaction with native membranes. We find that the conformation of $\alpha$-synuclein responds selectively to mitochondria, indicating a direct link between $\alpha$-synuclein and an organelle strongly implicated in the pathogenesis of PD.
\end{abstract}

Key words: synuclein; protein conformation; Parkinson's disease; mitochondria; neural degeneration; FRET

\section{Introduction}

The accumulation of misfolded protein is a defining feature of neurodegenerative disease. Characteristic proteins form amyloid deposits in different clinical disorders, and the aggregation can be reproduced in vitro. However, the role of aggregates in neural degeneration remains uncertain. In Huntington's disease, large aggregates may actually protect against toxicity (Klement et al., 1998; Saudou et al., 1998; Arrasate et al., 2004). In Alzheimer's disease, a relatively small assembly of $\mathrm{A} \beta$ peptide can impair memory (Lesné et al., 2006). The proteins that accumulate in neurodegenerative disease may thus produce toxicity through mechanisms that do not involve morphologically detectable aggregates. Oligomerization, misfolding or perhaps even the normal function of accumulating proteins may contribute to disease, but we know very little about the behavior of these proteins in cells before they form large aggregates.

The protein $\alpha$-synuclein appears to have a central role in the pathogenesis of sporadic as well as familial Parkinson's disease (PD). $\alpha$-Synuclein accumulates to high levels in Lewy bodies and dystrophic neurites, suggesting an important role in sporadic PD (Spillantini et al., 1997; Galvin et al., 1999). In addition, point mutations in $\alpha$-synuclein produce dominantly inherited forms of

Received July 2, 2008; revised 0ct. 4, 2008; accepted 0ct. 8, 2008.

This work was supported by a Postdoctoral Fellowship from the Hillblom Foundation and a Pilot Grant from the University of California at San Francisco (UCSF) Alzheimer's Disease Research Center (to K.N.), the UCSF Medical Scientist Training Program (V.M.N.), a predoctoral Fellowship from the Hillblom Foundation (V.M.N.), the Valley Foundation (R.H.E.), the National Parkinson Foundation (R.H.E.), and the Michael J. Fox Foundation (R.H.E.). We thank Marc Diamond for use of a fluorescent plate reader, Rebecca Howard and Dan Minor for assistance with CD spectroscopy, Bipasha Mukherjee for technical assistance, and Anthony Fink for helpful discussions.

Correspondence should be addressed to Robert $H$. Edwards, Departments of Neurology and Physiology, UCSF School of Medicine, 600 16th Street, GH-N272B, San Francisco, CA 94143. E-mail: robert.edwards@ucsf.edu.

DOI:10.1523/JNEUROSCI.3088-08.2008

Copyright $\odot 2008$ Society for Neuroscience ～0270-6474/08/2812305-13\$15.00/0
PD (Polymeropoulos et al., 1997; Krüger et al., 1998; Zarranz et al., 2004), indicating a causative role in pathogenesis. However, the mechanism by which $\alpha$-synuclein leads to neuronal degeneration in $\mathrm{PD}$, and indeed its normal function, remain unknown. The recent observation that a simple increase in gene dosage suffices to cause PD indicates a role for the wild type protein (Singleton et al., 2003), and suggests that PD may result either from a pathologic increase in normal function, or from the gain of an abnormal, toxic function. In the case of $\alpha$-synuclein, smaller aggregates have been observed in vitro using recombinant protein, possibly on the pathway to formation of amyloid fibrils, and these species have been proposed to cause cell death (Uversky et al., 2001a; Volles et al., 2001; Kaylor et al., 2005). However, there is no information about the state of $\alpha$-synuclein in a physiologically relevant context, within the cell.

It has been widely hypothesized that membrane interactions play a central role in the function and toxicity of $\alpha$-synuclein (Volles and Lansbury, 2007). A natively unfolded protein in solution, $\alpha$-synuclein adopts an $\alpha$-helical conformation on binding to artificial membranes containing acidic phospholipid (Davidson et al., 1998). In neurons, $\alpha$-synuclein localizes preferentially to the nerve terminal, and was originally identified as a peripheral membrane protein of synaptic vesicles (Maroteaux et al., 1988). $\alpha$-Synuclein has also been suggested to disrupt membrane trafficking (Outeiro and Lindquist, 2003; Willingham et al., 2003; Cooper et al., 2006). Despite tight binding to artificial membranes, however, $\alpha$-synuclein associates only weakly with native membranes (George et al., 1995; Kahle et al., 2000), and exhibits a high level of mobility by photobleaching experiments in transfected hippocampal neurons (Fortin et al., 2005). As a result, very little is known about the interaction of $\alpha$-synuclein with native membranes, or whether this even occurs in vivo. To study the interaction of $\alpha$-synuclein with membranes in a physiologically 
relevant context, we have introduced fluorophores that enable sensitive, rapid detection of the conformational changes associated with membrane binding.

\section{Materials and Methods}

Molecular biology. To create YFP- $\alpha$-synuclein (Ysyn) and $\alpha$-synucleinCFP (synC) fusion proteins, $\alpha$-synuclein was subcloned into pEYFP-C2 or pECFP-N1 vectors, respectively (Clontech), leaving EYFP separated from the $\mathrm{N}$ terminus of $\alpha$-synuclein by 7 residues (SGRTQIS), and ECFP from the $\mathrm{C}$ terminus by 5 residues (GSVAT). To prevent nonspecific dimerization between ECFP and EYFP, the L221K (Zacharias et al., 2002) mutation was introduced into both ECFP and EYFP. For FlAsH constructs, PCR mutagenesis was used to introduce the tetracysteine FlAsH binding motif (CCPGCC) directly adjacent to the $\mathrm{N}$ terminus of $\alpha$-synuclein. PCR mutagenesis was also used to introduce A30P, A53T and E46K mutations, and 4EBP1 was a generous gift from John Gross (University of California at San Francisco, San Francisco, CA). Constructs were subcloned into the chicken actin vector pCAGGs for expression in neurons. For bacterial expression, $\alpha$-synuclein fusion constructs were subcloned into the pGEX $5 \times-3$ vector (Amersham) immediately downstream of the Factor Xa cleavage site. A TEV cleavage site was also introduced into constructs with EYFP conjugated to the amino terminus of $\alpha$-synuclein.

Preparation of fusion proteins. Cultures of transformed E. coli strain BL21 (DE3) were induced with $100 \mu \mathrm{M}$ isopropyl-B-D-thiogalactopyranoside (IPTG) at A600 0.6-0.8, incubated for an additional $24 \mathrm{~h}$ at $16^{\circ} \mathrm{C}$, the bacteria sedimented, resuspended in PBS with $1 \mathrm{~mm}$ phenylmethanesulfonyl fluoride (PMSF) and $10 \mathrm{~mm}$ EDTA, disrupted by sonication, and the lysate sedimented at 14,500 $\mathrm{g}$ for $10 \mathrm{~min}$. The supernatant was incubated for $1 \mathrm{~h}$ at room temperature with glutathione Sepharose $4 \mathrm{~B}$ (Amersham). The beads were then washed, and fusion proteins isolated by cleavage overnight using either Factor Xa (Novagen) or TEV protease at $4^{\circ} \mathrm{C}$. For FlAsH labeling, proteins were reduced in $10 \mathrm{~mm}$ DTT, dialyzed into $100 \mu \mathrm{M}$ DTT, and conjugated for $24 \mathrm{~h}$ at $4^{\circ} \mathrm{C}$ with FlAsH-EDT2 at a molar ratio of $1: 1$ in a reaction mixture containing $1 \mathrm{~mm}$ 2-mercaptoethanol and $1 \mathrm{~mm}$ Triscarboxyethylphosphine-HCl (TCEP), following the manufacturers instructions. All proteins were dialyzed into $20 \mathrm{~mm} \mathrm{NaPO}_{4}$ pH 7.4 before use.

For experiments using COS lysates, cells were transfected by electroporation and cell lysates were harvested two $d$ later using sonication in SH buffer (0.32 m sucrose, 10 mm HEPES, pH 7.4). FRET experiments with COS lysates were performed in $25 \mathrm{~mm}$ MES and $80 \mathrm{~mm} \mathrm{NaCl}$.

Circular dichroism. The $\alpha$-helical content of untagged $\alpha$-synuclein and fusion proteins was assessed by circular dichroism in the absence of membranes, in the presence of membranes containing acidic phospholipid that can bind to $\alpha$-synuclein (binding lipid) or in the presence of membranes without acidic phospholipid that cannot bind to $\alpha$-synuclein (control lipid). Preparing liposomes as previously described (Kubo et al., 2005) from $10 \%$ cholesterol, $33 \%$ sphingomyelin, 33\% brain phosphatidylserine and $23 \%$ brain phosphatidylcholine (binding lipid) or from lipid containing $10 \%$ cholesterol, $33 \%$ sphingomyelin, $56 \%$ brain phosphatidylcholine (control lipid), $7.5 \mu \mathrm{m}$ fusion protein was incubated with $1.25 \mathrm{~mm}$ lipid in $20 \mathrm{~mm}$ sodium phosphate buffer, $\mathrm{pH} 7.4$ for 5 min at room temperature, and spectra were collected from 290 to $185 \mathrm{~nm}$ in 1 $\mathrm{nm}$ steps at $4^{\circ} \mathrm{C}$, using a $0.1 \mathrm{~cm}$ quartz cuvette in an Aviv Model 215 spectropolarimeter. The final spectra reflect the contribution of $\alpha$-synuclein alone, obtained by subtracting out the spectra of lipids and buffer. For fusion proteins, the spectra of CFP (and YFP for YsynC) were also subtracted. Data were expressed as mean residue ellipticity $[\theta]^{*} 1000$, where $[\theta]=(\mathrm{MW}) /(\mathrm{N}-1)^{\star} \mathrm{C}^{\star} 1$, where $\mathrm{MW}=$ molecular weight of protein, $\mathrm{N}=$ number of amino acid residues per protein, $\mathrm{C}=$ concentration of protein $(\mathrm{mg} / \mathrm{ml})$ and $1=$ path length of cell in $\mathrm{mm}\left(\mathrm{deg} \mathrm{cm}^{2} / \mathrm{dmol}\right)$.

In vitro FRET. FRET of purified proteins was assayed in a 96 well plate using a fluorescent plate reader with the following excitation/emission parameters: CFP (435 nm ex/485 nm em), YFP or FlAsH (508 nm ex/527 $\mathrm{nm} \mathrm{em}$ ) and FRET (435 nm ex/527 nm em), as previously described (Pollitt et al., 2003). FRET calculations were corrected for independent contributions of the acceptor (YFP) and donor (CFP) to the FRET fluo- rescence channel (Weatherman et al., 2002), which were determined using singly tagged $\alpha$-synuclein fusion proteins (e.g., synC or synY), measuring the average background corrected fluorescence of each construct in the CFP, YFP and FRET channels. The fraction of YFP signal that derives from excitation of the $435 \mathrm{~nm}$ channel (i.e., the YFP crossover excitation, $\mathrm{X}_{\mathrm{YFP}}$ ) was determined as $\mathrm{X}_{\mathrm{YFP}}=\mathrm{YFP}_{\mathrm{FRET}} / \mathrm{YFP}_{\mathrm{YFP}}$. FRET/donor ratio was then calculated according to the formula: FRET/ donor $=\left(\right.$ FRET $($ measured $)-\left[\mathrm{YFP}(\right.$ measured $\left.\left.) \times \mathrm{X}_{\mathrm{YFP}}\right]\right) / \mathrm{CFP}($ measured). For all quantitative analysis of FRET, mean \pm SEM (SEM) were calculated, and the significance of differences between groups determined using either two-tailed $t$ test or ANOVA followed by NewmanKeuls post hoc test.

Optical imaging in live cells. HeLa cells and mesencephalic neurons were transfected by electroporation (Amaxa) with either YsynC, synC and synY, synC and Ysyn or YC. HeLa cells were studied two d after transfection. Mesencephalic neurons were prepared from ventral midbrain dissected from gestation day 14 rat embryos (Sprague Dawley) as previously described (Nakamura et al., 2001), and imaged after 12-16 d in culture. For microinjection experiments, subconfluent HeLa cells (80\%) were cultured for $2 \mathrm{~d}$ and nuclear microinjections of $60 \mu \mathrm{m}$ purified protein in phosphate buffer were performed at room temperature with an automated injection system (Eppendorf Micromanipulator 5171 together with Eppendorf Transjector 5246), as described previously (Pagans et al., 2005). Cells were imaged live three to four $\mathrm{h}$ after microinjection.

FRET was measured after photobleaching the entire cell body or bouton. Neuronal cell bodies and boutons were bleached by illumination four times at 100\% laser power with a $514 \mathrm{~nm}$ laser (cropped 3.5 $\times$ ), and HeLa cell bodies by illumination 40 times at the same power (no cropping), in both cases using a Zeiss LSM 510 confocal microscope and $100 \times$ oil objective. For boutons, an area of $3.1 \mu \mathrm{m} * 1.8 \mu \mathrm{m}$ was bleached, and $3.5 \mu \mathrm{m} \star 2 \mu \mathrm{m}$ was monitored. For cell bodies, the bleached area corresponded to the size of the cell body (typically $15-25 \mu \mathrm{m}$ by $10-20$ $\mu \mathrm{m})$. In all experiments, CFP and YFP/FlAsH fluorescence were imaged four times before and after bleaching to establish stable baselines.

Preparation of native membranes. Synaptosomal fractions LP2, LS2 and LP1 were prepared as previously described (Kubo et al., 2005). Brain mitochondria were prepared using the method of Lai and Clark (1989). Briefly, 5- to 6-week-old rats were anesthesized, decapitated, and the brains homogenized in $320 \mathrm{~mm}$ sucrose, 4 mм Hepes-Tris, pH 7.4, $1 \mathrm{~mm}$ $\mathrm{MgCl}_{2}, 1 \mathrm{~mm}$ EDTA, PMSF and pepstatin A with a $25 \mathrm{ml}$ loose-fitting glass-Teflon homogenizer (Kontes Glass, \#22) using 10 strokes at 500 $\mathrm{rpm}$. The homogenate was then sedimented at $1300 \mathrm{~g}$ for $3 \mathrm{~min}$, the supernatant sedimented at 17,000 $\mathrm{g}$ for $10 \mathrm{~min}$, and the resulting pellet resuspended in cold $\mathrm{SH}$ buffer with $1 \mathrm{~mm}$ EDTA (isolation medium) before sedimentation through a Ficoll step gradient $(10 \%-7.5 \%)$ at $99,000 \mathrm{~g}$ for $30 \mathrm{~min}$.

Liver mitochondria were isolated according to Susin et al. (2000). Briefly, rat livers were minced, homogenized in $300 \mathrm{~mm}$ saccharose, $5 \mathrm{~mm}$ TES (N-tris(hydroxymethyl)methyl-2-aminoethanesulfonic acid), 200 $\mu \mathrm{M}$ EGTA, pH 7.2 (H buffer), sedimented at $746 \mathrm{~g}$ for $10 \mathrm{~min}$, and the resulting supernatant at $8635 \mathrm{~g}$ for $10 \mathrm{~min}$. The pellet was then resuspended in $\mathrm{H}$ buffer, layered over a Percoll step gradient $(18 \%-30 \%-$ $60 \%$ ), sedimented for an additional $10 \mathrm{~min}$ at $8740 \mathrm{~g}$, and mitochondria isolated from the $30-60 \%$ Ficoll interface washed with $\mathrm{H}$ buffer, and resuspended in $20 \mathrm{mM} \mathrm{NaPO}_{4}$, $\mathrm{pH} 7.4$.

Crude endoplasmic reticulum (ER) was prepared from rat liver by homogenizing the minced tissue in isotonic extraction buffer ( $250 \mathrm{~mm}$ sucrose, $25 \mathrm{~mm}$ potassium chloride, $1 \mathrm{~mm}$ EGTA and $10 \mathrm{~mm}$ HEPES, $\mathrm{pH}$ 7.8), sedimenting at $1000 \mathrm{~g}$ for $10 \mathrm{~min}$, and the resulting supernatant at $12,000 \mathrm{~g}$ for 15 min (Depierre and Dallner, 1976). The supernatant was then sedimented at $100,000 \mathrm{~g}$ for $60 \mathrm{~min}$ and resuspended in $20 \mathrm{mM} \mathrm{NaPO}_{4}, \mathrm{pH}$ 7.4.

Western blot analysis. To determine the content of endogenous $\alpha$-synuclein in subcellular fractions, $50 \mu \mathrm{g}$ of isolated brain mitochondria, liver mitochondria, ER, LP1, LP2 or LS2 protein was separated by electrophoresis through SDS-polyacrylamide, and immunoblotted for endogenous synuclein (SYN1 antibody; BD Biosciences), synaptophysin (S5768; Sigma), complex V ATPase (A21350; Invitrogen), cytochrome C (556433; BD Biosciences), calreticulin (SPA-600; Stressgen) and sodium potassium ATPase (ab7671; Abcam). In other experiments, COS lysates 
A
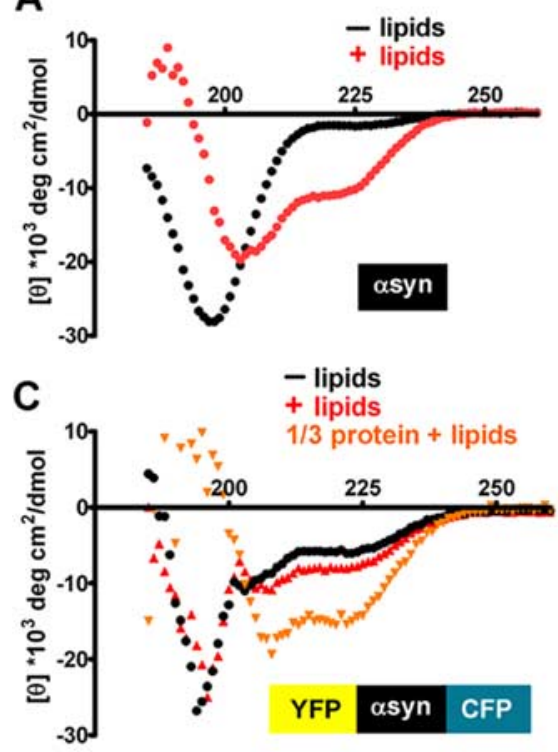

E

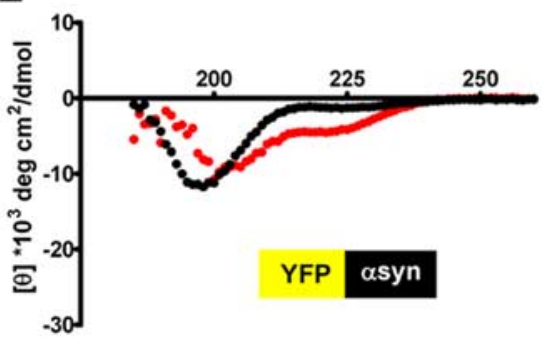

G

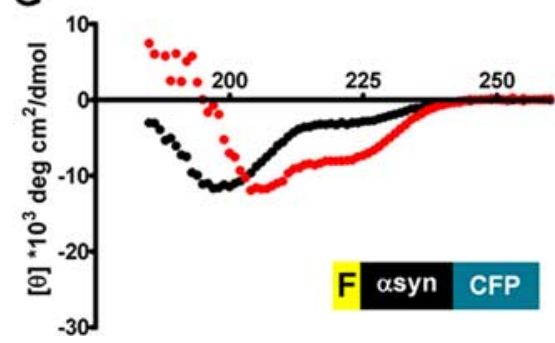

B

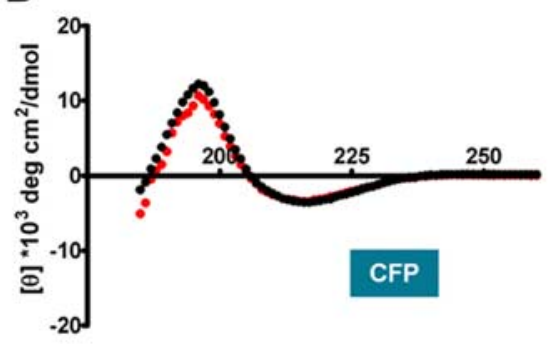

D

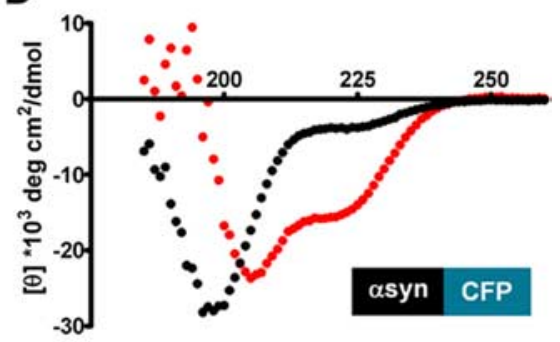

$\mathbf{F}$

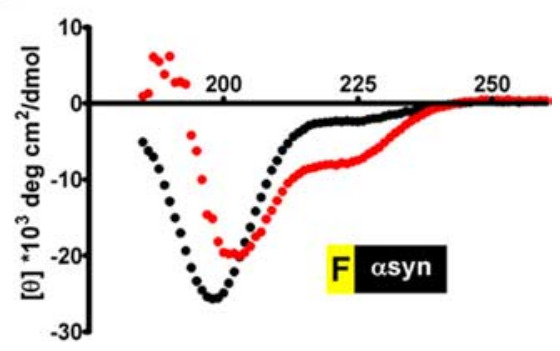

$\mathrm{NaPO}_{4}, \mathrm{pH}$ 7.4, separated by electrophoresis through SDS-polyacrylamide, transferred to PVDF membranes and immunostained for human synuclein (15G7, Alexis Biochemicals), synaptophysin, ATP synthase and the $\mathrm{Na} / \mathrm{K}$ ATPase.

\section{Results \\ Development of an intramolecular FRET reporter}

To develop probes capable of detecting the conformation of $\alpha$-synuclein, we first characterized in vitro a series of recombinant, bacterially expressed proteins by the same methods previously used to study the untagged protein. The $\mathrm{N}$ terminus of $\alpha$-synuclein contains 7 imperfect, 11 residue repeats that form a broken amphipathic helix during membrane association (Eliezer et al., 2001; Chandra et al., 2003). Because $\alpha$-synuclein is considered a natively unfolded protein in solution, the $\alpha$-helical conformation that accompanies membrane binding might be expected to bring the ends of the protein in closer proximity. To monitor the distance between the ends of $\alpha$-synuclein by fluorescence resonance energy transfer (FRET), we therefore introduced YFP onto the $\mathrm{N}$ terminus, and CFP onto the $\mathrm{C}$ terminus. Considering the large size of these fluorescent proteins relative to $\alpha$-synuclein (16 $\mathrm{kDa}$ ), and their potential to perturb the behavior of synuclein, we first used circular dichroism (CD) spectroscopy to monitor the change in conformation on binding of purified recombinant protein to artificial membranes that contain the acidic phospholipid phosphatidylserine (Kubo et al., 2005).

Untagged wild-type human $\alpha$-synuclein $(7.5 \mu \mathrm{M})$ shows the characteristic $\alpha$-helical shift previously reported on addition of membranes (1250 $\mu \mathrm{M}, 167: 1$ lipid:protein molar ratio) (Fig. 1 $A$ ) (Davidson et al., 1998). In contrast, CFP alone (Fig. $1 B$ ) and YFP alone (data not shown) exhibit no change in CD spectra in the presence of these membranes. We then used CD spectroscopy to study the fusion of YFP to the $\mathrm{N}$ terminus of $\alpha$-synuclein and CFP to the C terminus (YsynC), subtracting the spectra obtained for equal molar concentrations of YFP and CFP alone to yield the spectrum for synuclein (Fig. 1C). YsynC shows somewhat less $\alpha$-helical shift than the untagged protein, but a threefold re-

were immunoblotted for GFP (A11122; Molecular Probes) and visualized using an Odyssey Infrared Imaging System (Li-Cor Biosciences).

Binding to native membranes. To compare the binding of exogenous, recombinant human $\alpha$-synuclein to different native membranes, 10 or $100 \mathrm{~nm}$ purified human synuclein was incubated with $2.5 \mathrm{mg} / \mathrm{ml}$ brain mitochondria, LP1 or LP2 for $15 \mathrm{~min}$ at room temperature in $200 \mu \mathrm{l}$ of isolation medium containing PMSF. Reaction mixtures were then diluted to $13.5 \mathrm{ml}$ in isolation buffer, sedimented at 260,000 $\mathrm{g}$ for $1 \mathrm{~h}$, the resulting pellet washed once with isolation buffer, resuspended in $20 \mathrm{~mm}$ duction in the amount of recombinant protein (to $2.5 \mu \mathrm{M}$ ) restores the shift. The increased lipid:protein ratio presumably compensates for a small loss of affinity for membranes, and indicates that YsynC can undergo the same conformational change as untagged $\alpha$-synuclein. To determine which of the two fusions might have impaired the affinity of YsynC, we examined recombinant synC and Ysyn separately, again subtracting the spectra for 
CFP and YFP alone. In contrast to synC which shows a helical shift (Fig. 1D) similar to the untagged protein, Ysyn shows less change on membrane association (Fig. $1 E)$, although an $\mathrm{N}$-terminal fusion to GFP exhibits synaptic localization similar to wild type $\alpha$-synuclein in transfected neurons (Fortin et al., 2005). To reduce the size of the N-terminal fluorophore, we introduced a tetracysteine motif into the $\mathrm{N}$ terminus of $\alpha$-synuclein and conjugated the purified, bacterially expressed protein in vitro with the biarsenical reagent $\mathrm{FlAsH}$ (Griffin et al., 2000). FlAsH- $\alpha$-synuclein (Fsyn) shows a helical shift on membrane binding very similar to untagged $\alpha$-synuclein (Fig. $1 F$ ). We then introduced the FlAsH fluorophore into synC and found that FsynC also demonstrates a strong $\alpha$-helical shift by CD (Fig. $1 G$ ).

\section{$\alpha$-Synuclein adopts a closed state in solution}

Although $\alpha$-synuclein is considered a natively unfolded protein, the YsynC fusion protein exhibits considerable FRET at baseline (Fig. 2A). Further, a mixture of Fsyn and synC, and of CFP and YFP, both show no FRET, excluding intermolecular interactions as the source of this signal. Because fusion of YFP to the $\mathrm{N}$ terminus of synuclein affects its behavior by CD (Fig. 1), we also examined FsynC, and detected similar but slightly less baseline FRET, presumably because the CFP-FlAsH pair cannot transfer energy over the same distance as CFP-YFP (Siegel et al., 2000) (L. Munishkina and A. Fink, personal communication) (Fig. 2A). The results indicate proximity of the $\mathrm{N}$ and $\mathrm{C}$ termini, which could reflect either their chance interaction in a natively unfolded protein, or a more structured closed conformation.

To determine whether the baseline FRET reflects a native conformation of synuclein, we first used denaturation in urea. Previous work has shown that GFP and FlAsH are resistant to denaturation by high concentrations of urea (Ignatova and Gierasch, 2004; Alkaabi et al., 2005). We indeed observed no effect of $7.5 \mathrm{M}$ urea on the FRET exhibited by a direct fusion of the two fluorophores (synCF). In contrast, urea substantially reduces the FRET signal of YsynC and FsynC (Fig. 2 B), indicating a specific disruption of $\alpha$-synuclein structure, and supporting the existence of a closed conformation in solution. Previous work has indeed suggested that urea disrupts dipole coupling by the synuclein $\mathrm{C}$ terminus, implicating long-range interactions in the native state (Bertoncini et al., 2005b). However, the residual FRET in urea also suggests a role for chance interaction of the two fluorophores in the intramolecular FRET by synuclein reporters.

To characterize further the closed conformation of $\alpha$-synuclein, we tested the effects of salt concentration on FRET by FsynC (Fig. 2C). The FRET is substantially higher at low salt concentrations $(<100 \mathrm{~mm})$ and declines as the concentration of salt increases. FRET remains detectable at even the highest salt concentration tested ( $400 \mathrm{~mm} \mathrm{NaCl})$, and may under these con-
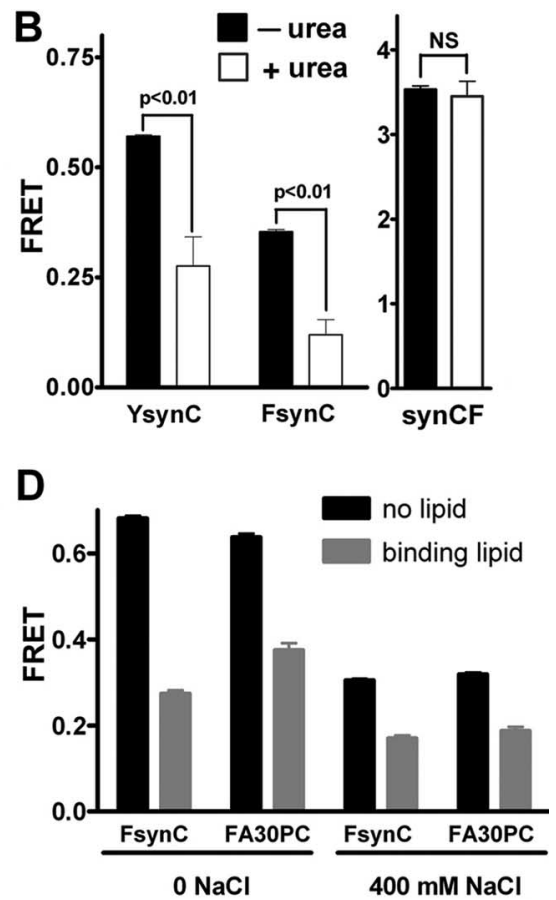

Figure 2. Intramolecular FRET reveals a closed conformation for $\alpha$-synuclein. $\boldsymbol{A}$, The FRET of 400 nM recombinant YFPsynuclein-CFP (YsynC), CFP with YFP (C+Y), FIAsH-synuclein-CFP (FsynC) and FIAsH-synuclein with synuclein-CFP (Fsyn + synC)

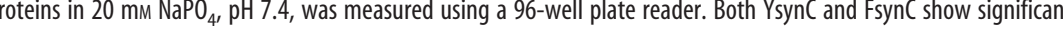
列 absence or presence of $400 \mathrm{~mm} \mathrm{NaCl}$ and $3 \mathrm{~mm} \mathrm{NaPO}_{4}, \mathrm{pH}$ 7.4. In low salt, the A3OP mutation inhibits the reduction in FRET but has no substantial effect in the presence of $400 \mathrm{~mm} \mathrm{NaCl}$. The values indicate mean $\pm \mathrm{SEM} ; n=7-8$ wells per condition.

ditions reflect some combination of both hydrophobic interactions and chance fluorophore proximity.

Membranes disrupt the relatively closed state of $\alpha$-synuclein We also used the FRET-based reporters to determine how the conformation of $\alpha$-synuclein changes on membrane association. The addition of artificial membranes containing acidic phospholipid reduces the FRET exhibited by YsynC, and FsynC shows a similar decrease (Fig. 3A). However, the FRET shown by FsynC is slightly more sensitive than that of YsynC to increasing concentrations of membranes (at $75 \mu \mathrm{M}, p<0.001$ for FsynC and $p=$ 0.45 for YsynC relative to no lipid controls, two-tailed $t$ test), consistent with the higher apparent affinity of FsynC for membranes observed by CD. Importantly, membranes with acidic phospholipid have no effect on the FRET of direct fusion synCF. In addition, similar membranes without acidic phospholipid have no effect on the FRET of FsynC and YsynC, even at the highest concentrations (Fig. $3 A$ ), reflecting the specific requirement of $\alpha$-synuclein for membranes containing acidic phospholipids (Davidson et al., 1998). To assess further the specificity of this interaction, we examined the competition between $400 \mathrm{nM}$ FsynC and increasing concentrations of untagged synuclein (Fig. $3 B$ ). The decrease in FRET caused by membrane binding was reduced at $200 \mathrm{~nm}$ untagged synuclein and almost eliminated at 750 

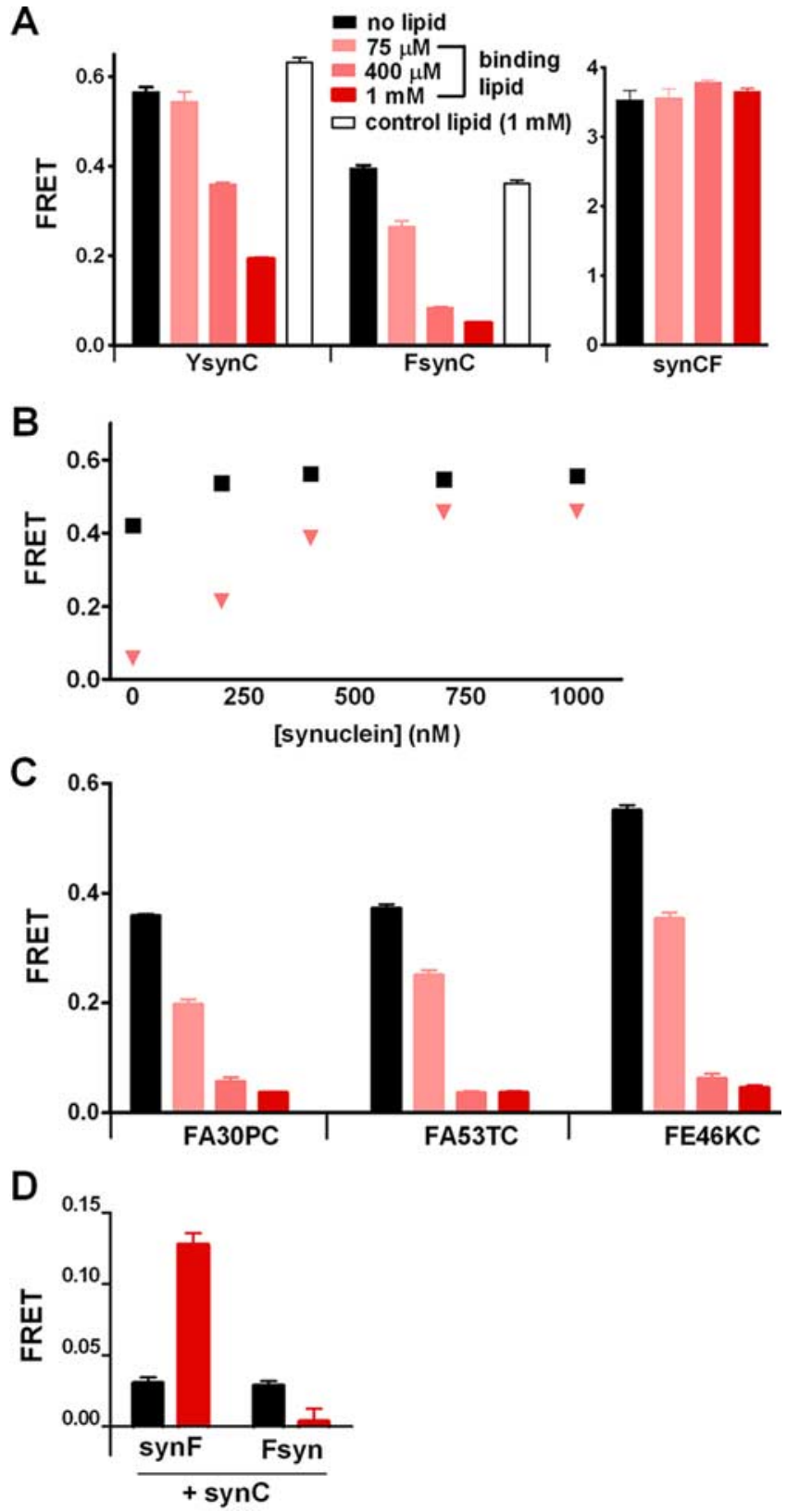

Figure 3. Membrane association reduces the intramolecular FRET of $\alpha$-synuclein. $\boldsymbol{A}$, YsynC, FsynC and synCF fusion proteins ( $400 \mathrm{~nm}$ ) were incubated with increasing concentrations of membranes containing $10 \%$ cholesterol, $33 \%$ sphingomyelin, $33 \%$ brain phosphatidylserine and $23 \%$ brain phosphatidylcholine (binding lipids), or with $1 \mathrm{~mm}$ membranes containing 33\% cholesterol, 33\% sphingomyelin, 33\% brain phosphatidylcholine (control lipids). YsynC and FsynC both show a progressive reduction in FRET at higher binding lipid concentrations, whereas the maximum concentration of control lipids has no effect. The direct fusion synCF shows high FRET not affected by the presence of binding lipids. The results show mean $\pm \mathrm{SEM} ; n=4-16$ wells per condition. $\boldsymbol{B}$, FsynC fusion proteins ( $400 \mathrm{~nm}$ ) were added to binding lipids $(400 \mu \mathrm{M})$ and increasing concentrations of untagged $\alpha$-synuclein. Incubation with binding lipids decreases the FRET of Fsync, and this decrease is reduced by coincubation with untagged $\alpha$-synuclein at concentrations as low as $200 \mathrm{~nm}$. The results show mean \pm SEM; $n=4-12$ wells per condition. C, FsynC mutant fusion proteins were incubated with increasing concentrations of binding lipids. In the absence of membranes, FE46KC shows higher intramolecular FRET than wild type or the other mutants. In the presence of membranes, however, the FRET decreases to a similar extent for all proteins. Data show mean $\pm \mathrm{SEM} ; n=4-12$ wells per condition. $\boldsymbol{D}$, synC fusion proteins ( $400 \mathrm{~nm}$ ) were incubated with either Fsyn or synF, in the presence or absence of binding lipid ( $1 \mathrm{mM}$ ). In the presence of lipid, an increase in intermolecular FRET is detected in the presence of synF, but not Fsyn. Data show mean \pm SEM; $n=20$ wells per condition.
nM. The change in FRET thus appears to reflect a specific interaction with membranes, supporting the physiological relevance of the observed changes in $\alpha$-synuclein conformation. The requirement for concentrations of untagged synuclein similar to those of FsynC also supports the relatively native conformation of the reporter.

To assess the effect of point mutations known to cause PD on the behavior of $\alpha$-synuclein, we introduced the A30P, A53T and E46K mutations into the FsynC construct. All of the mutants exhibit substantial FRET in solution, but the E46K mutant shows more FRET than the others, including wild type $\alpha$-synuclein (Fig. $2 C)$. Indeed, E46K FsynC exhibits more FRET than the other mutants and wild type $\alpha$-synuclein at $\mathrm{NaCl}$ concentrations up to $100 \mathrm{~mm}(p<0.01$ relative to wild type at 0,20 and $50 \mathrm{~mm}$, and $p<0.05$ at $100 \mathrm{~mm}$, by two-way ANOVA followed by NewmanKeuls post hoc test). In contrast, both A30P FsynC and A53T FsynC show less FRET than wild type at up to $100 \mathrm{~mm} \mathrm{NaCl}(p<$ 0.01 at $0,20,50$ and $100 \mathrm{~mm}$ for A30P FsynC, $p<0.01$ at 0,20 , and $50 \mathrm{~mm}$ and $p<0.05$ at $100 \mathrm{~mm}$ for A53T FsynC). Artificial membranes containing acidic phospholipid also reduce the FRET of PD-associated FsynC mutants, with a potency similar to that observed for the wild type protein (Fig. $3 C$ ). Although the A30P mutation has little effect on the interaction of $\alpha$-synuclein with artificial membranes (Perrin et al., 2000; Bussell and Eliezer, 2004), it disrupts the enrichment of $\alpha$-synuclein at synapses (Fortin et al., 2004), and we do observe that in low salt, membranes cause a proportionately smaller reduction in FRET by the A30P FsynC mutant relative to wild type (Fig. $2 D)(p<0.01$ by threeway ANOVA followed by Newman-Keuls post hoc test). At 400 $\mathrm{mM} \mathrm{NaCl}$, however, the A30P mutation does not affect either baseline FRET or the change in FRET with membranes. In addition, both wild type and A30P $\alpha$-synuclein show a proportionately smaller reduction in FRET at high salt than low, consistent with the dependence of synuclein membrane binding on ionic as well as hydrophobic interactions (Davidson et al., 1998).

To determine whether the changes in FRET observed with recombinant protein purified from bacteria would also occur in cell extracts, we used transient expression in COS cells. Crude COS cell extracts show minimal degradation of $\mathrm{N}$ - and C-terminal fusion proteins (supplemental Fig. $1 \mathrm{~A}$, available at www.jneurosci.org as supplemental material), and substantial baseline FRET of YsynC but not isolated CFP + YFP or Ysyn + synC reporters (supplemental Fig. $1 B$, available at www. jneurosci.org as supplemental material). Similar to the bacterially expressed protein, YsynC expressed in COS cells also shows a substantial reduction in FRET on membrane binding (supplemental Fig. $1 B$, available at www.jneurosci.org as supplemental material). To determine whether the ability of membranes to reduce intramolecular FRET is restricted to the $\alpha$-synuclein isoform, we also examined COS cell extracts expressing $\beta$-synuclein $(\mathrm{Y} \beta$ synC). As suggested by the sequence similarity between $\mathrm{N}$-terminal membrane binding domains and the similar $\alpha$-helical shift by circular dichroism in the presence of membranes (Sung and Eliezer, 2006), Y $\beta$ synC also shows baseline FRET and a reduction in FRET on membrane binding (supplemental Fig. $1 C$, available at www.jneurosci.org as supplemental material).

We then took advantage of this system to determine whether the $\mathrm{C}$ terminus of $\alpha$-synuclein is required for membrane association, using constructs that contain either residues $1-80$ or $1-100$ from synuclein fused at the $\mathrm{N}$ terminus to YFP and at the $\mathrm{C}$ terminus to CFP (Ysyn80C and Ysyn100C). Consistent with the reduced distance between fluorophores, both truncation mutants exhibit higher baseline FRET than wild type synuclein, but still show a reduction in FRET on binding specifically to mem- 
branes that contain acidic phospholipid (supplemental Fig. $1 C, D$, available at www.jneurosci.org as supplemental material). However, the A30P mutation essentially eliminates the reduction in FRET on membrane binding by Ysyn80C, indicating a more profound effect of the mutation on membrane binding by $\alpha$-synuclein in the absence of the $\mathrm{C}$ terminus.

To assess further the contribution of chance fluorophore interactions to the intramolecular FRET observed at baseline by the synuclein reporters, we made a FRET reporter using 4EBP1, a 118 amino acid protein that is also generally considered to be natively unfolded (Fletcher et al., 1998). At baseline, Y4EBP1C shows FRET greater than that of full-length $\alpha$-synuclein (140 aa) but less than that of a deletion mutant lacking the $40 \mathrm{C}$-terminal residues of synuclein, suggesting either that chance interactions contribute to the intramolecular FRET of synuclein reporters or, as previously suggested, that $4 \mathrm{EBP} 1$ retains some residual structure (Wang et al., 2003). Indeed, it may be very difficult to identify normal cellular proteins that do not exhibit any native conformation. Most important, however, the intramolecular FRET of Y4EBP1C does not decrease on exposure to membranes, in contrast to the behavior of $\alpha$-synuclein. Although the analysis of 4EBP1 suggests a role for chance proximity in the intramolecular FRET by synuclein reporters, the effects of urea and salt also indicate a more structured, closed conformation, and the effect of membranes shows that the state of synuclein in solution is closed at least relative to its open conformation on membrane binding.

Because the interaction of $\alpha$-synuclein with vesicles has been reported to promote oligomer formation (Perrin et al., 2001), we also assessed intermolecular FRET in the presence of membranes capable of binding synuclein (Fig. 3D). Interestingly, the combination of synF and synC shows a small but definite signal for intermolecular FRET, whereas the combination of Fsyn and synC show no detectable signal. A small fraction of membrane-bound synuclein thus does form oligomers, and in the oligomeric state, the $\mathrm{C}$ termini lie closer to each other than to the $\mathrm{N}$ termini. The absence of FRET in the Fsyn and synC group also confirms that the residual FRET signal from FsynC on binding lipids is composed entirely of intramolecular FRET (rather than intermolecular FRET).

\section{The conformation of $\alpha$-synuclein in live cells}

To assess the conformation of $\alpha$-synuclein in living cells, we transfected HeLa cells with the YsynC reporter and measured FRET by photobleaching the YFP acceptor (Fig. 4A, B). Because FRET requires distances between donor and acceptor fluorophores $<5-10 \mathrm{~nm}$, changes in FRET reflect alterations in protein conformation that cannot be resolved by standard light microscopy (Patterson et al., 2000). Although laborious, acceptor pho- tobleaching also avoids artifacts that may arise with other methods, and provides definitive information about FRET (Snapp and Hegde, 2006). As previously observed in live cells, the vast majority of $\alpha$-synuclein in cultured cells distributes freely in the cytoplasm (Fortin et al., 2005). Photobleaching also reveals a diffusely distributed signal for intramolecular FRET, with no significant intermolecular FRET using the combinations of synC and synY and synC and Ysyn (Fig. 4A,B). A substantial fraction of the $\alpha$-synuclein in cells thus adopts a closed conformation, presumably not bound to membrane.

Because the FsynC construct exhibits a slightly higher apparent affinity for membranes than YsynC by both CD and FRET, we also transfected HeLa cells with FsynC and labeled the transfected cells with FlAsH (Griffin et al., 2000; Poskanzer et al., 2003; Hoffmann et al., 2005). However, the conditions required for labeling produced toxicity and an unacceptable level of nonspecific, background fluorescence. For this reason, we microinjected HeLa cells with $60 \mu \mathrm{M}$ purified recombinant protein labeled in vitro 
A

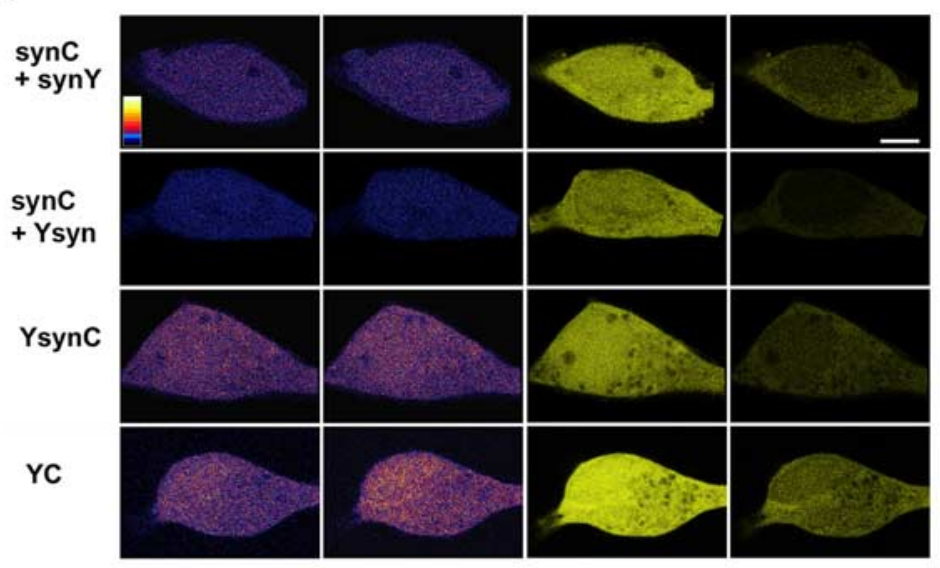

B
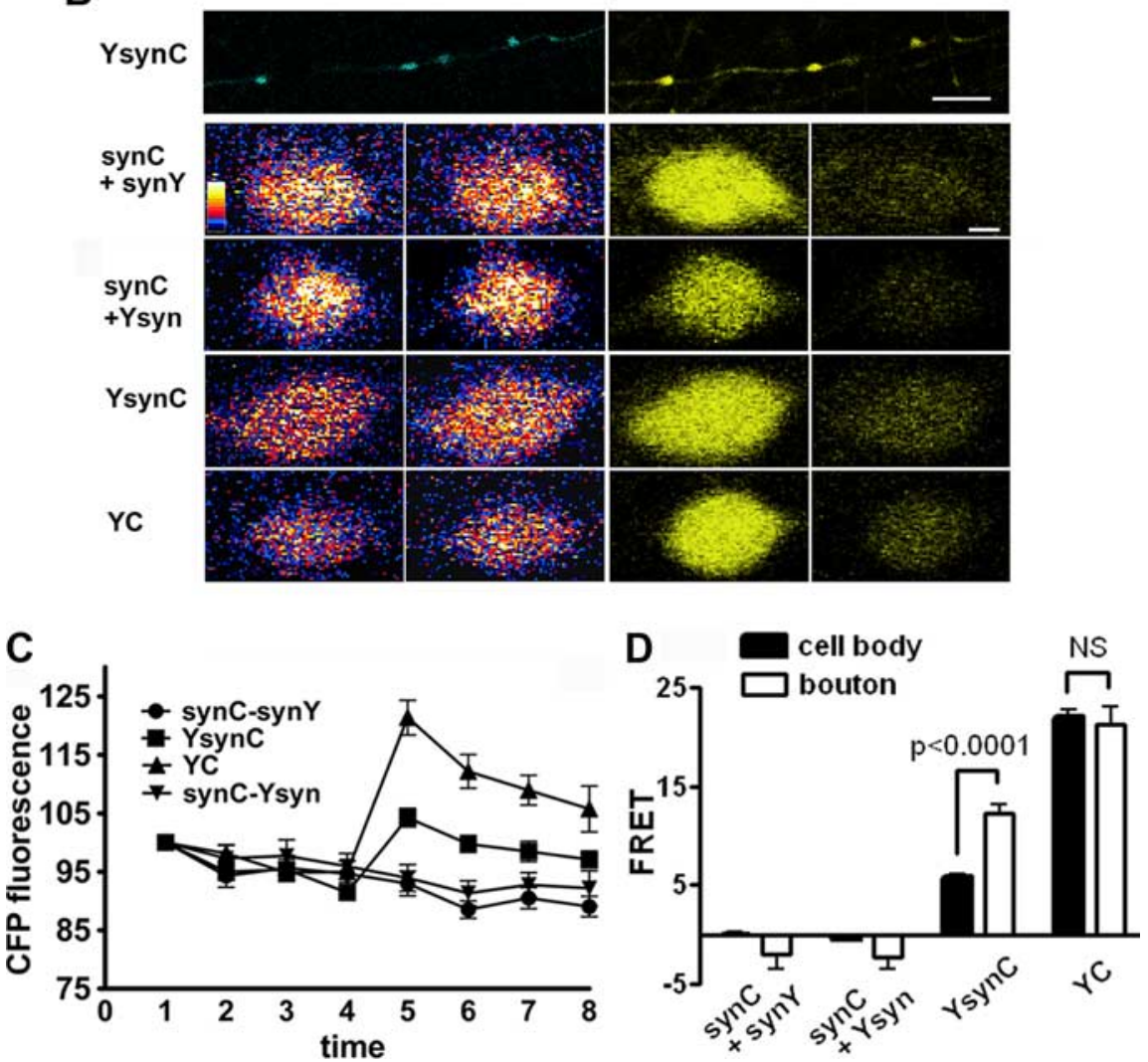

Figure 5. $\alpha$-Synuclein adopts a closed conformation in neurons. $\boldsymbol{A}, \boldsymbol{B}$, Mesencephalic neurons were transfected with either synC and synY, synC and Ysyn, YsynC or the direct fusion Y-C, and cultured for 14-17 d. FRET was then measured in neuronal cell bodies $(\boldsymbol{A})$ and synaptic boutons $(\boldsymbol{B})$ by acceptor photobleaching. Images show CFP and YFP fluorescence, before and after bleaching. Scale bars: $\boldsymbol{A}, 5 \mu \mathrm{m} ; \boldsymbol{B}, 5 \mu \mathrm{m}$ and $0.5 \mu \mathrm{m}$ for low- and high-power images, respectively. $\boldsymbol{C}$, Neurons were imaged four times to establish a baseline, then photobleached and four more images were collected. Synaptic boutons expressing YsynC and the direct fusion Y-C but not the intermolecular pairs of synC and synY or synC and Ysyn show an increase in fluorescence of CFP with photobleaching. D, Quantitation of the data from multiple cell bodies and synaptic boutons shows detectable FRET in both locations, although greater in boutons. The values indicate mean $\pm \mathrm{SEM} ; n=11-24$ per group.

with FlAsH. After microinjection, FsynC exhibits modest but definite intramolecular FRET, with no intermolecular FRET detected using the combination of Fsyn and synC (Fig. 4C). To compare the extent of FRET in different experimental systems, we calculated the ratio of mean FsynC FRET/SynCF FRET. In HeLa cells, this ratio $(0.145 \pm 0.08)$ exceeds that observed using purified recombinant protein in the absence of any membranes $(0.11 \pm 0.01)$, whereas the same ratio in the presence of $1 \mathrm{~mm}$ artificial membranes containing acidic phospholipid is $0.014 \pm$
0.001, supporting a predominantly closed conformation for $\alpha$-synuclein in $\mathrm{HeLa}$ cells. We also detected no spatial variation in FRET to suggest a local membrane interaction. However, the $\alpha$-synuclein fusion proteins produced in living cells can undergo a conformational change in the presence of lipid: extracts from transfected cells expressing YsynC show a clear reduction in FRET on addition of artificial membranes containing acidic phospholipid (supplemental Fig. 1, available at www.jneurosci.org as supplemental material).

To assess the conformation of $\alpha$-synuclein in living neurons, we transfected primary midbrain cultures with YsynC. Similar to the positive YC fusion control, raw donor fluorescence increases after photobleaching, with no change in fluorescence using the intermolecular reporters synC and synY or synC and Ysyn (Fig. 5A-D). Individual cell bodies expressing the $\mathrm{YC}$ fusion and $\mathrm{YsynC}$ but not the synC-synY or synC-Ysyn pair consistently show an increase in fluorescence after photobleaching (supplemental Fig. 2, available at www.jneurosci.org as supplemental material). However, the donor fluorescence of YsynC increases to a greater extent in boutons than cell bodies (Figs. $5 D, S 2)$. The ratio of YsynC FRET/YC FRET is $0.261 \pm 0.091$ in neuronal cell bodies and a remarkable $0.577 \pm 0.280$ in neuronal boutons, higher than that observed in HeLa cells $(0.343 \pm 0.0979)$ and cell extracts without added membranes $(0.26 \pm 0.03)$. It is important to note that the measurements at bouton and cell body were obtained under very similar imaging conditions, including magnification, laser intensity and number of iterations for bleaching. Only the scan time was longer for cell bodies than boutons, because of the difference in size. Despite the longer scan time, YFP fluorescence at the cell body exhibits very little recovery from photobleaching. In the case of YsynC, recovery at the cell body was $11.3 \pm 0.978 \%(n=5)$ over $\sim 25-50 \mathrm{~s}$ (the time required for four images after bleaching, depending on the size of the cell body). In contrast, YFP fluorescence at the bouton recovered $40.1 \pm$ $1.66 \%(n=24)>7-8$ s, presumably because of the presence of unbleached, mobile protein in the adjacent axon and neighboring boutons. Because the movement of unbleached protein into the bleached area during the bleach would reduce the extent of FRET, the FRET measured in boutons is an underestimate of the true value.

The FRET observed in neurons does not depend on the concentration of the FsynC reporter. Indeed, we deliberately selected boutons and cell bodies with similar levels of YFP fluorescence, and detected no correlation between initial YFP fluorescence and FRET (supplemental Fig. 3B, available at www.jneurosci.org as 
supplemental material). Further, in vitro experiments show only a very small increase in FRET for FsynC over a 16-fold change in concentration (supplemental Fig. $3 A$, available at www.jneurosci.org as supplemental material), much smaller than the effects of membrane binding. Nonetheless, for all of the in vivo studies, we have selected for analysis cells exhibiting low levels of fluorescence to avoid potential artifacts of over-expression. It is also possible that synaptic boutons simply contain more membrane than cell bodies, but we found that the membrane interaction now characterized by many groups in vitro reduces rather than increases FRET by the YsynC and FsynC reporters. Undefined conditions at synaptic boutons thus promote the closed conformation of $\alpha$-synuclein, whereas cell bodies favor a more open conformation, suggesting distinct interactions at these two sites. In previous work, we found that synaptic activity results in the dispersion of $\alpha$-synuclein from boutons, but we have thus far failed to detect any associated change in FRET (data not shown), probably because any conformational change would affect the protein lost rapidly from the field of view, and the protein that remains does not change conformation.

We also found no evidence for intermolecular FRET in vivo. The FRET pair synF and synY (Fig. 3D) and others (unpublished observations, A. Fink) can detect oligomers and the initial stages of fibrillation, but we did not observe FRET using these intermolecular reporters in vivo, suggesting that the preponderance of $\alpha$-synuclein in living neurons is monomeric. A small fraction of $\alpha$-synuclein may exist in oligomeric form, but at levels lower than we can detect.

Binding to native membranes reveals an interaction with mitochondria

To characterize the factors that might account for the different conformation of $\alpha$-synuclein at synaptic boutons and cell bodies, we examined its interaction with native membranes, again using the FRET-based reporters. Although the tight binding of $\alpha$-synuclein to artificial membranes in vitro and the associated conformational change strongly suggest that membrane binding occupies an important place in the function of $\alpha$-synuclein, previous work has indicated that $\alpha$-synuclein binds only weakly to membranes in vivo (Kahle et al., 2000; Fortin et al., 2005). In addition, the presence of endogenous membrane proteins makes it impossible to study $\alpha$-synuclein binding to native membranes by $\mathrm{CD}$, and the low affinity of interaction may preclude detection by the relatively slow biochemical methods required for separating free from bound protein. The predominantly closed conformation observed by FRET is consistent with partial or weak binding in cells, but intramolecular FRET also provides a simple assay for the interaction of $\alpha$-synuclein with native membranes in vitro. The loss of FRET by YsynC and FsynC on membrane binding is essentially instantaneous, and compatible with the presence of nonfluorescent endogenous proteins. In addition, use of the FRET assay in vitro enables us to increase the lipid: protein ratio, and this is crucial to detect the interaction of synuclein even with artificial membranes.

Because $\alpha$-synuclein localizes predominantly to presynaptic boutons in neurons, we first measured FRET of both YsynC and FsynC in the presence of rat brain synaptic plasma membrane fraction LP1, synaptic vesicle fraction LP2 and soluble synaptic fraction LS2 (Fig. 6A). However, none of these fractions (at up to $2.5 \mathrm{mg}$ protein $/ \mathrm{ml}$ ) reduce the baseline FRET of YsynC or FsynC. In fact, both reporters show a small increase in FRET in the pres- 
ence of these fractions, consistent with the high FRET observed at synaptic boutons in vivo (Fig. 6).

Considering the substantial evidence implicating mitochondria in the pathogenesis of PD, we also investigated the interaction of YsynC and FsynC with mitochondria. In contrast to synaptic membrane fractions, mitochondria prepared from rat brain produce a clear, dose-dependent decrease in FRET for both reporters (Fig. $6 B$ ). Because endogenous $\alpha$-synuclein might compete with the fluorescent reporters for binding, we also used mitochondria from the liver, which does not express synuclein. Liver mitochondria reduce the FRET of both reporters even more dramatically (Fig. 6B), strongly supporting a direct interaction of $\alpha$-synuclein with mitochondria. Although a recent report has described the energy-dependent import of $\alpha$-synuclein into mitochondria (Devi et al., 2008), it is important to note that the interaction we observe is essentially instantaneous. As observed with artificial membranes, $\mathrm{PD}$-associated mutations have little effect on the sensitivity of FsynC FRET to brain mitochondria, although the magnitude of change was greater with E46K because of a higher baseline level of FRET (Fig. 6D).

Because mitochondrial preparations frequently contain contaminating endoplasmic reticulum (ER) (supplemental Fig. 4, available at www.jneurosci.org as supplemental material), we further tested the interaction of synuclein with purified ER. Indeed, we detected the ER protein calreticulin in both brain and to a greater extent, liver mitochondria (supplemental Fig. $4 B$, available at www.jneurosci.org as supplemental material). In contrast to mitochondria, however, purified ER (which contains very small amounts of cytochrome C) (supplemental Fig. $4 B$, available at www.jneurosci.org as supplemental material) fails to reduce FRET of the FsynC reporter. In fact, the FRET increases slightly in the presence of liver ER, for unclear reasons (Fig. 6C). We find no evidence of intermolecular FRET between Fsyn and synC in the presence of any membranes tested (LP1, LP2, LS2, brain mitochondria, liver mitochondria or ER) (data not shown).

To assess an interaction with mitochondria using biochemical methods, we examined the distribution of $\alpha$-synuclein in rat membrane and nonmembrane fractions by Western analysis. Figure 7A shows the largest amount of endogenous $\alpha$-synuclein in synaptic cytosol fraction LS2, presumably because most of the protein is soluble. Among membrane fractions normalized either by protein content (Fig. 7A) or by percentage of starting material (supplemental Fig. S4A, available at www.jneurosci.org as supplemental material), however, the synaptic plasma membrane fraction LP1 (enriched in $\mathrm{Na}^{+} / \mathrm{K}^{+}$-ATPase) contains substantially more endogenous $\alpha$-synuclein than the synaptic vesicle fraction LP2 (enriched in synaptophysin) with which $\alpha$-synuclein has generally been considered to associate. Because LP1 contains more mitochondrial ATP synthase than LP2, the fractionation of $\alpha$-synuclein correlates with the amount of mitochondria. Further, purified brain mitochondria contain more $\alpha$-synuclein than any of the other membrane fractions when standardized by protein content (Fig. 7A), but levels similar to LP1 when standardized by percentage of starting material (supplemental Fig. S4, available at www.jneurosci.org as supplemental material).

Because differences in preparation might account for the varying levels of $\alpha$-synuclein in different membranes, we also used sedimentation followed by Western analysis to assess the binding of untagged, recombinant human $\alpha$-synuclein. Figure $7 B$ shows that $100 \mathrm{~nm}$ exogenous $\alpha$-synuclein binds more tightly to LP1 than LP2, and LP1 again contains more mitochondrial ATP synthase than LP2. Exogenous $\alpha$-synuclein binds still more
A

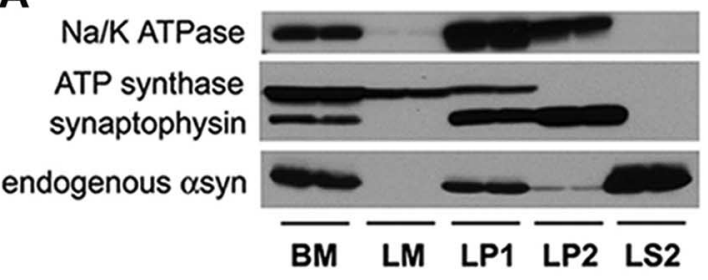

B

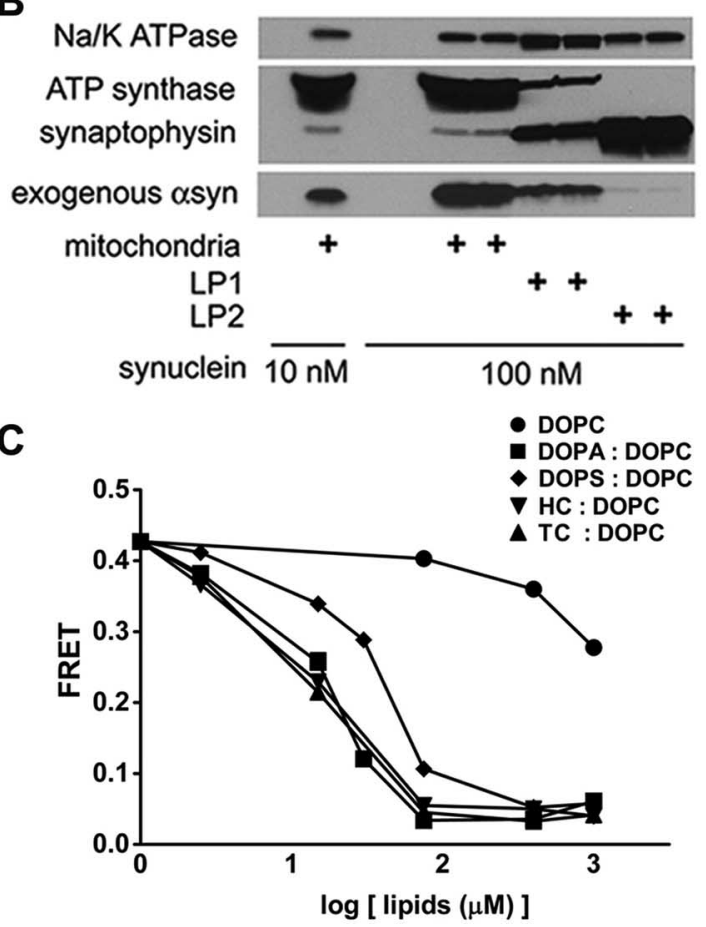

Figure 7. Brain mitochondria contain endogenous $\alpha$-synuclein and bind to exogenous $\alpha$-synuclein. $\boldsymbol{A}$, Purified rat brain mitochondria (BM) and liver mitochondria (LM), and synaptosomal fractions LP1 (synaptic plasma membrane), LP2 (synaptic vesicles), and LS2 (synaptic cytosol) were immunoblotted for endogenous $\alpha$-synuclein as well as for the plasma membrane $\mathrm{Na} / \mathrm{K}$ ATPase, mitochondrial ATP synthase and the synaptic vesicle protein synaptophysin. In addition to a large soluble pool in $L S 2$, endogenous $\alpha$-synuclein shows preferential enrichment in brain mitochondria, and to a lesser extent in LP1, which also contains mitochondrial ATP synthase. $B$, Brain mitochondria, LP1 and LP2 were incubated with recombinant untagged human $\alpha$-synuclein (at 10 or $100 \mathrm{~nm}$ ) for $15 \mathrm{~min}$ at room temperature before dilution, sedimentation, and immunoblotting the pelleted membranes with an antibody specific to human $\alpha$-synuclein. C, FsynC (400 nM) was incubated with increasing concentrations of artificial liposomes containing DOPA:DOPC (1:1 molar ratio), DOPA: DOPS (1:1), heart cardiolipin (HC):DOPC (1:1), 1,1,2,2-tetraoleoyl cardiolipin (TC):DOPC (1:1), or DOPC alone, and the FRET measured. The values indicate mean \pm SEM; $n=4-8$ wells per group.

strongly to brain mitochondria, even at a 10-fold lower concentration $(10 \mathrm{~nm})$. Both the distribution of endogenous $\alpha$-synuclein in brain fractions, and the binding of exogenous $\alpha$-synuclein to these brain fractions thus correlate with the content of mitochondria, supporting the significance of changes in synuclein conformation observed by FRET in the presence of mitochondria. In contrast to previous work focusing on the interaction of synuclein only with mitochondria ( $\mathrm{Li}$ et al., 2007; Devi et al., 2008), the analysis by both fluorescence and biochemical methods demonstrates that the interaction of $\alpha$-synuclein with mitochondria is selective. The reduced FRET at cell bodies may thus reflect a specific association of synuclein with mitochondria.

To determine whether the binding of $\alpha$-synuclein might depend on mitochondrial activity, we depolarized brain mitochondria with the proton ionophore FCCP $(10 \mu \mathrm{M})$. At this concen- 
tration, FCCP entirely dissipates mitochondrial membrane potential. Consistent with this, preincubation of isolated brain mitochondria with FCCP for 5 min decreased the accumulation of 50 nM Mito Tracker Red CMXRos (M7512; Invitrogen), from $227 \pm 19.5$ (untreated) to $127 \pm 26.0$ arbitrary fluorescence units (treated). The residual Mitotracker Red in the presence of FCCP has been described previously (Brown et al., 2006) and may represent membrane potential-independent binding of the dye to mitochondria. However, FCCP has no effect on the change in FRET produced by these mitochondria using FsynC as the reporter (Fig. $6 E)$. Thus, the interaction of $\alpha$-synuclein with mitochondria does not appear to depend on the functional status of this organelle.

Because mitochondria contain large amounts of the acidic phospholipid cardiolipin, and $\alpha$-synuclein is known to require acidic phospholipids for binding to artificial membranes, we assessed specifically a potential interaction with cardiolipin. Over a range of membrane concentrations, we found that like vesicles containing phosphatidic acid (1,2-dioleoyl-sn-glycero-3phophate, DOPA), vesicles containing either heart cardiolipin (HC) or synthetic 1,1,2,2-tetraoleoyl cardiolipin (TC) potently reduce the FRET of FsynC, and vesicles containing only phosphatidylcholine (1,2-dioleoyl-sn-glycero-3-phosphocholine, DOPC) have $>200$-fold lower apparent affinity (Fig. 7C). The dose-response analysis shows no difference in apparent affinity among HC, TC, or phosphatidic acid. However, $\alpha$-synuclein has a somewhat lower affinity for vesicles containing phosphatidylserine (1,2-dioleoyl-sn-glycero-3-[phospho-L-serine], DOPS) ( $p<0.05$ than vesicles containing phosphatidic acid at $2.5 \mu \mathrm{M}$, and $p<0.01$ at 15,30 and $75 \mu \mathrm{M}$ by two way ANOVA followed by Newman-Keuls post hoc test). Although $\alpha$-synuclein requires acidic head groups for association with membranes, it thus prefers phosphatidic acid and cardiolipin to phosphatidylserine.

\section{Discussion \\ $\alpha$-Synuclein adopts a relatively closed conformation in vitro and in vivo}

The results described here provide evidence for a relatively closed state of $\alpha$-synuclein in vitro and in living cells. In particular, we observe FRET between the $\mathrm{N}$ and $\mathrm{C}$ termini of $\alpha$-synuclein both in vitro and in vivo. Characterized first in vitro using recombinant protein, the interaction is intramolecular because we do not observe FRET between singly tagged proteins. The analysis of $4 \mathrm{EBP} 1$, another natively unfolded protein of similar size, suggests that the intramolecular FRET by synuclein reporters may reflect the chance proximity of fluorophores. However, we also find that urea disrupts their FRET without affecting the FRET exhibited by a direct fusion of the fluorescent proteins. Salt also reduces the extent of FRET, consistent with previous results suggesting a native conformation maintained by electrostatic interactions (Bertoncini et al., 2005b). Although $\alpha$-synuclein behaves like a natively unfolded protein by CD and other methods (Weinreb et al., 1996; Uversky et al., 2001b), more recent studies using paramagnetic relaxation enhancement and NMR dipolar couplings (Bertoncini et al., 2005b; Dedmon et al., 2005) have indeed demonstrated long-range interactions between the $\mathrm{C}$ terminus and other domains of $\alpha$-synuclein, as well as an intrinsic fold involving the $\mathrm{N}$-terminal 28 residues. Another study using $\mathrm{H}-\mathrm{N}$-Heteronuclear single quantum coherence (HSQC) spectra also describes an increase in secondary structure within the first $\mathrm{N}$-terminal 100 aa that becomes more prominent with temperature (McNulty et al., 2006).

\section{Membrane association converts $\alpha$-synuclein from closed to open conformation}

Exposure to artificial membranes with acidic phospholipids dramatically reduces the baseline FRET of YsynC and FsynC, indicating that the ends of $\alpha$-synuclein move apart on membrane binding. Previous EPR studies have indeed suggested that $\alpha$-synuclein forms an elongated helical structure on binding small unilamellar vesicles (Jao et al., 2004). Presumably, membrane association displaces the $\mathrm{C}$ terminus of $\alpha$-synuclein from the $\mathrm{N}$-terminal membrane-binding domain, or at least separates the $\mathrm{N}$ and $\mathrm{C}$ termini, thus reducing the likelihood of chance proximity.

What is the physiological role of a shift in $\alpha$-synuclein conformation from closed to open on membrane binding? Analogy to other proteins involved in signal transduction suggests that the change in conformation may serve to regulate the function of $\alpha$-synuclein. Phosphorylation disrupts the closed conformation of src-family nonreceptor tyrosine kinases, exposing the active site and enabling phosphorylation of substrates (Cooper and Howell, 1993). Similarly, the activation of protein kinase C by translocation to the plasma membrane involves destabilization of a closed state (Oancea and Meyer, 1998; Schechtman et al., 2004). We speculate that $\alpha$-synuclein may also undergo activation by membrane binding. If $\alpha$-synuclein acts directly on membranes, the $\mathrm{C}$ terminus may simply serve to regulate the function of the $\mathrm{N}$-terminal membrane-binding domain. Alternatively, membrane binding may activate the function of the acidic $\mathrm{C}$ terminus.

\section{$\alpha$-Synuclein binds specifically to mitochondria}

$\alpha$-Synuclein has generally been considered to associate with synaptic vesicles. It was originally purified in association with synaptic vesicles from the Torpedo electric organ (Maroteaux et al., 1988), and is clearly enriched at presynaptic boutons (Fortin et al., 2005). However, it has been very difficult to demonstrate direct binding of $\alpha$-synuclein to any native membrane fraction (George et al., 1995; Kahle et al., 2000). The evidence of high mobility by FRAP and a predominantly closed state by FRET are consistent with weak membrane interactions in vivo. Nonetheless, the analysis of FRET has also enabled us to assay the membrane binding of $\alpha$-synuclein in vitro. In particular, the instantaneous change in FRET on membrane addition eliminates any requirement for separation of free from bound protein. The attachment of fluorophore to $\alpha$-synuclein rather than lipid also permits the analysis of native membranes, with their own endogenous but unlabeled proteins. We now find that synaptic membranes do not substantially affect the FRET of recombinant $\alpha$-synuclein. Rather, mitochondria, and particularly those from the liver which do not contain endogenous $\alpha$-synuclein, dramatically reduce the FRET of YsynC and FsynC.

Considering the robust interaction of $\alpha$-synuclein with mitochondria, why have many studies failed to observe a mitochondrial localization (Withers et al., 1997; Rideout et al., 2003; Fortin et al., 2005)? The previous analysis by circular dichroism (Zhu and Fink, 2003) and our current work using FRET-based reporters suggest a simple explanation. Even in vitro, membrane binding can only be detected at high lipid: protein ratios, presumably because the excess of membrane drives an intrinsically weak interaction with limited binding sites. In living cells, however, the lipid: protein ratio is almost certainly lower, allowing unbound synuclein to obscure any bound fraction. Nonetheless, a small bound fraction may well be crucial for the physiological role of synuclein, as it is for many other peripheral membrane proteins. However, several recent studies have begun to suggest a mitochondrial localization for $\alpha$-synuclein in fixed cells under normal 
as well as pathologic conditions (Martin et al., 2006; Li et al., 2007; Devi et al., 2008; Cole et al., 2008; Shavali et al., 2008; Zhang et al., 2008). The specificity of this localization has been difficult to assess, but FRET-based and biochemical assays now show that $\alpha$-synuclein interacts specifically with mitochondria.

The interaction of $\alpha$-synuclein with mitochondria raises additional questions. First, how can the binding of synuclein to mitochondria be reconciled with its presynaptic enrichment? Many but not all axon terminals contain mitochondria (Shepherd and Harris, 1998), and $\alpha$-synuclein generally shows little localization to cell body and dendrites, which contain abundant mitochondria. $\alpha$-Synuclein may also interact with synaptic membranes, but without the same change in conformation produced by artificial membranes or mitochondria. However, it is important to note that in midbrain dopamine neurons, the cells vulnerable to degeneration in PD, $\alpha$-synuclein often occurs at relatively high levels in the cell body (Mori et al., 2002; Andringa et al., 2003; Rideout et al., 2003; Zhang et al., 2008). In addition, both MPTP toxicity and sporadic PD involve accumulation of $\alpha$-synuclein in the cell body (Purisai et al., 2005; Mori et al., 2006), possibly as a result of its interaction with mitochondria. Although we have not detected the mitochondrial enrichment of $\alpha$-synuclein in living cells by optical imaging, the relatively low FRET observed in neuronal cell bodies may nonetheless reflect the interaction of $\alpha$-synuclein with mitochondria.

Second, how might $\alpha$-synuclein interact specifically with mitochondria? Depolarization does not affect binding to $\alpha$-synuclein, suggesting that the functional state of the mitochondria is less important than other factors, such as lipid composition. Mitochondria contain large amounts of the acidic phospholipid cardiolipin, primarily on inner membranes, but also on outer (Daum, 1985; Sperka-Gottlieb et al., 1988; Hovius et al., 1993; Liu et al., 2003). Considering the requirement for acidic phospholipid in binding to artificial membranes, these concentrations may increase the affinity for $\alpha$-synuclein. Consistent with this possibility, we find that $\alpha$-synuclein binds equally well to cardiolipin and phosphatidic acid. Importantly, $\alpha$-synuclein binds less strongly to phosphatidylserine, indicating specificity among the acidic phospholipids.

\section{Implications for PD}

The results have implications for the pathogenesis of PD. The association of $\alpha$-synuclein with membranes might be expected to protect against its aggregation. An $\alpha$-helical shift produced by membrane binding presumably reduces the likelihood of adopting the $\beta$-sheet conformation found in amyloid fibrils (Conway et al., 2000). However, displacement of the $\mathrm{C}$ terminus by membranes may have the opposite effect, allowing the membranebinding domain to form fibrils. Indeed, truncation of the $\mathrm{C}$ terminus dramatically increases the fibrillation of $\alpha$-synuclein, and has been used to produce a robust transgenic model for synucleinopathy (Serpell et al., 2000; Tofaris et al., 2006). An open conformation may expose hydrophobic sequences within the membrane-binding $\mathrm{N}$ terminus, allowing the protein to aggregate (Bertoncini et al., 2005b). The higher proportion of open conformation synuclein in cell bodies relative to synaptic boutons may thus predispose to misfolding specifically at this site.

All of the PD-associated mutations influence the conformation of $\alpha$-synuclein in vitro, although the specific effect varies. A30P and A53T mutations both reduce the closed conformation, consistent with increased structural fluctuation and reduced shielding of the internal hydrophic domain (Bertoncini et al., 2005a). At low salt concentrations, however, membrane binding has less effect on A30P than wild type or A53T $\alpha$-synuclein, as previously reported (Jo et al., 2002). In contrast, E46K has a more closed conformation in solution, and previous work has indeed reported an increased retention time for this mutant by size exclusion chromatography (Fredenburg et al., 2007). The change in FRET produced by membranes further indicates that the more closed conformation of E46K $\alpha$-synuclein does not present an obvious impediment to membrane association.

Although not previously linked to $\alpha$-synuclein, considerable work has suggested a central role for mitochondrial dysfunction in PD. PD has been associated with a defect in mitochondrial complex I (Schapira et al., 1990), and brain mitochondria from patients with PD accumulate more mutations than unaffected controls (Bender et al., 2006). In addition, several genes responsible for mendelian forms of PD have been suggested to associate with mitochondria (Canet-Avilés et al., 2004; Valente et al., 2004; Biskup et al., 2006), and mutations in two (parkin and PINK1) produce severe mitochondrial abnormalities in Drosophila flight muscle (Greene et al., 2003; Clark et al., 2006; Park et al., 2006).

Previous work has also raised the possibility of an interaction between synuclein and mitochondria. Mice lacking $\alpha$-synuclein are relatively resistant to the mitochondrial neurotoxin 1-methyl-4-phenyl-1,2,3,6-tetrahydropyridine (MPTP) (Dauer et al., 2002) and other mitochondrial toxins (Klivenyi et al., 2006). In addition, cells and transgenic mice expressing wild type and mutant synuclein develop marked mitochondrial degeneration (Hsu et al., 2000; Smith et al., 2005; Martin et al., 2006; Stichel et al., 2007). Further, the loss of $\alpha$-synuclein leads to a selective decrease in the mitochondrial lipid cardiolipin (Ellis et al., 2005). The results reported here suggest that these observations may reflect a direct interaction of synuclein with mitochondria.

\section{References}

Alkaabi KM, Yafea A, Ashraf SS (2005) Effect of pH on thermal- and chemicalinduced denaturation of GFP. Appl Biochem Biotechnol 126:149-156.

Andringa G, Du F, Chase TN, Bennett MC (2003) Mapping of rat brain using the Synuclein-1 monoclonal antibody reveals somatodendritic expression of alpha-synuclein in populations of neurons homologous to those vulnerable to Lewy body formation in human synucleopathies. J Neuropathol Exp Neurol 62:1060-1075.

Arrasate M, Mitra S, Schweitzer ES, Segal MR, Finkbeiner S (2004) Inclusion body formation reduces levels of mutant huntingtin and the risk of neuronal death. Nature 431:805-810.

Bender A, Krishnan KJ, Morris CM, Taylor GA, Reeve AK, Perry RH, Jaros E, Hersheson JS, Betts J, Klopstock T, Taylor RW, Turnbull DM (2006) High levels of mitochondrial DNA deletions in substantia nigra neurons in aging and Parkinson disease. Nat Genet 38:515-517.

Bertoncini CW, Fernandez CO, Griesinger C, Jovin TM, Zweckstetter M (2005a) Familial mutants of alpha-synuclein with increased neurotoxicity have a destabilized conformation. J Biol Chem 280:30649-30652.

Bertoncini CW, Jung YS, Fernandez CO, Hoyer W, Griesinger C, Jovin TM, Zweckstetter M (2005b) Release of long-range tertiary interactions potentiates aggregation of natively unstructured alpha-synuclein. Proc Natl Acad Sci U S A 102:1430-1435.

Biskup S, Moore DJ, Celsi F, Higashi S, West AB, Andrabi SA, Kurkinen K, Yu SW, Savitt JM, Waldvogel HJ, Faull RL, Emson PC, Torp R, Ottersen OP, Dawson TM, Dawson VL (2006) Localization of LRRK2 to membranous and vesicular structures in mammalian brain. Ann Neurol 60:557-569.

Brown SV, Hosking P, Li J, Williams N (2006) ATP synthase is responsible for maintaining mitochondrial membrane potential in bloodstream form Trypanosoma brucei. Eukaryot Cell 5:45-53.

Bussell R Jr, Eliezer D (2004) Effects of Parkinson's disease-linked mutations on the structure of lipid-associated alpha-synuclein. Biochemistry 43:4810-4818

Canet-Avilés RM, Wilson MA, Miller DW, Ahmad R, McLendon C, Bandyopadhyay S, Baptista MJ, Ringe D, Petsko GA, Cookson MR (2004) The Parkinson's disease protein DJ-1 is neuroprotective due to cysteine- 
sulfinic acid-driven mitochondrial localization. Proc Natl Acad Sci U S A 101:9103-9108.

Chandra S, Chen X, Rizo J, Jahn R, Südhof TC (2003) A broken alpha -helix in folded alpha -Synuclein. J Biol Chem 278:15313-15318.

Clark IE, Dodson MW, Jiang C, Cao JH, Huh JR, Seol JH, Yoo SJ, Hay BA, Guo M (2006) Drosophila pink1 is required for mitochondrial function and interacts genetically with parkin. Nature 441:1162-1166.

Cole NB, Dieuliis D, Leo P, Mitchell DC, Nussbaum RL (2008) Mitochondrial translocation of alpha-synuclein is promoted by intracellular acidification. Exp Cell Res 314:2076-2089.

Conway KA, Harper JD, Lansbury PT Jr (2000) Fibrils formed in vitro from alpha-synuclein and two mutant forms linked to Parkinson's disease are typical amyloid. Biochemistry 39:2552-2563.

Cooper AA, Gitler AD, Cashikar A, Haynes CM, Hill KJ, Bhullar B, Liu K, Xu K, Strathearn KE, Liu F, Cao S, Caldwell KA, Caldwell GA, Marsischky G, Kolodner RD, Labaer J, Rochet JC, Bonini NM, Lindquist S (2006) Alpha-synuclein blocks ER-Golgi traffic and Rab1 rescues neuron loss in Parkinson's models. Science 313:324-328.

Cooper JA, Howell B (1993) The when and how of Src regulation. Cell 73:1051-1054.

Dauer W, Kholodilov N, Vila M, Trillat AC, Goodchild R, Larsen KE, Staal R, Tieu K, Schmitz Y, Yuan CA, Rocha M, Jackson-Lewis V, Hersch S, Sulzer D, Przedborski S, Burke R, Hen R (2002) Resistance of alpha-synuclein null mice to the parkinsonian neurotoxin MPTP. Proc Natl Acad Sci U S A 99:14524-14529.

Daum G (1985) Lipids of mitochondria. Biochim Biophys Acta 822:1-42.

Davidson WS, Jonas A, Clayton DF, George JM (1998) Stabilization of alpha-synuclein secondary structure upon binding to synthetic membranes. J Biol Chem 273:9443-9449.

Dedmon MM, Lindorff-Larsen K, Christodoulou J, Vendruscolo M, Dobson CM (2005) Mapping long-range interactions in alpha-synuclein using spin-label NMR and ensemble molecular dynamics simulations. J Am Chem Soc 127:476-477.

Depierre J, Dallner G (1976) Isolation, subfractionation and characterization of the endoplasmic reticulum. In: Biocehmical analysis of membranes (Maddy AH, ed), pp 79-131. New York: Wiley.

Devi L, Raghavendran V, Prabhu BM, Avadhani NG, Anandatheerthavarada HK (2008) Mitochondrial import and accumulation of alpha-synuclein impair complex I in human dopaminergic neuronal cultures and Parkinson disease brain. J Biol Chem 283:9089-9100.

Eliezer D, Kutluay E, Bussell R Jr, Browne G (2001) Conformational properties of alpha-synuclein in its free and lipid-associated states. J Mol Biol 307:1061-1073.

Ellis CE, Murphy EJ, Mitchell DC, Golovko MY, Scaglia F, Barceló-Coblijn GC, Nussbaum RL (2005) Mitochondrial lipid abnormality and electron transport chain impairment in mice lacking alpha-synuclein. Mol Cell Biol 25:10190-10201.

Fletcher CM, McGuire AM, Gingras AC, Li H, Matsuo H, Sonenberg N, Wagner G (1998) 4E binding proteins inhibit the translation factor eIF4E without folded structure. Biochemistry 37:9-15.

Fortin DL, Troyer MD, Nakamura K, Kubo S, Anthony MD, Edwards RH (2004) Lipid rafts mediate the synaptic localization of alpha-synuclein. J Neurosci 24:6715-6723.

Fortin DL, Nemani VM, Voglmaier SM, Anthony MD, Ryan TA, Edwards RH (2005) Neural activity controls the synaptic accumulation of alphasynuclein. J Neurosci 25:10913-10921.

Fredenburg RA, Rospigliosi C, Meray RK, Kessler JC, Lashuel HA, Eliezer D, Lansbury PT Jr (2007) The impact of the E46K mutation on the properties of alpha-synuclein in Its monomeric and oligomeric states. Biochemistry 46:7107-7118.

Galvin JE, Uryu K, Lee VM, Trojanowski JQ (1999) Axon pathology in Parkinson's disease and Lewy body dementia hippocampus contains alpha-, beta-, and gamma-synuclein. Proc Natl Acad Sci U S A 96:13450-13455.

George JM, Jin H, Woods WS, Clayton DF (1995) Characterization of a novel protein regulated during the critical period for song learning in the zebra finch. Neuron 15:361-372.

Greene JC, Whitworth AJ, Kuo I, Andrews LA, Feany MB, Pallanck LJ (2003) Mitochondrial pathology and apoptotic muscle degeneration in Drosophila parkin mutants. Proc Natl Acad Sci U S A 100:4078-4083.

Griffin BA, Adams SR, Jones J, Tsien RY (2000) Fluorescent labeling of recombinant proteins in living cells with FlAsH. Methods Enzymol 327:565-578.

Hoffmann C, Gaietta G, Bünemann M, Adams SR, Oberdorff-Maass S, Behr
B, Vilardaga JP, Tsien RY, Ellisman MH, Lohse MJ (2005) A FlAsHbased FRET approach to determine $\mathrm{G}$ protein-coupled receptor activation in living cells. Nat Methods 2:171-176.

Hovius R, Thijssen J, van der Linden P, Nicolay K, de Kruijff B (1993) Phospholipid asymmetry of the outer membrane of rat liver mitochondria. Evidence for the presence of cardiolipin on the outside of the outer membrane. FEBS Lett 330:71-76.

Hsu LJ, Sagara Y, Arroyo A, Rockenstein E, Sisk A, Mallory M, Wong J, Takenouchi T, Hashimoto M, Masliah E (2000) alpha-Synuclein promotes mitochondrial deficit and oxidative stress. Am J Pathol 157:401-410.

Ignatova Z, Gierasch LM (2004) Monitoring protein stability and aggregation in vivo by real-time fluorescent labeling. Proc Natl Acad Sci U S A 101:523-528.

Jao CC, Der-Sarkissian A, Chen J, Langen R (2004) Structure of membranebound alpha-synuclein studied by site-directed spin labeling. Proc Natl Acad Sci U S A 101:8331-8336.

Jo E, Fuller N, Rand RP, St George-Hyslop P, Fraser PE (2002) Defective membrane interactions of familial Parkinson's disease mutant A30P alpha-synuclein. J Mol Biol 315:799-807.

Kahle PJ, Neumann M, Ozmen L, Muller V, Jacobsen H, Schindzielorz A, Okochi M, Leimer U, van Der Putten H, Probst A, Kremmer E, Kretzschmar HA, Haass C (2000) Subcellular localization of wild-type and Parkinson's disease-associated mutant alpha -synuclein in human and transgenic mouse brain. J Neurosci 20:6365-6373.

Kaylor J, Bodner N, Edridge S, Yamin G, Hong DP, Fink AL (2005) Characterization of oligomeric intermediates in alpha-synuclein fibrillation: FRET studies of Y125W/Y133F/Y136F alpha-synuclein. J Mol Biol 353:357-372.

Klement IA, Skinner PJ, Kaytor MD, Yi H, Hersch SM, Clark HB, Zoghbi HY, Orr HT (1998) Ataxin-1 nuclear localization and aggregation: role in polyglutamine-induced disease in SCA1 transgenic mice. Cell 95:41-53.

Klivenyi P, Siwek D, Gardian G, Yang L, Starkov A, Cleren C, Ferrante RJ, Kowall NW, Abeliovich A, Beal MF (2006) Mice lacking alphasynuclein are resistant to mitochondrial toxins. Neurobiol Dis 21:541-548.

Krüger R, Kuhn W, Müller T, Woitalla D, Graeber M, Kösel S, Przuntek H, Epplen JT, Schöls L, Riess O (1998) Ala30Pro mutation in the gene encoding alpha-synuclein in Parkinson's. Nat Genet 18:106-108.

Kubo S, Nemani VM, Chalkley RJ, Anthony MD, Hattori N, Mizuno Y, Edwards RH, Fortin DL (2005) A combinatorial code for the interaction of alpha-synuclein with membranes. J Biol Chem 280:31664-31672.

Lai JC, Clark JB (1989) Isolation and characterization of synaptic and nonsynaptic mitochondria from mammalian brain. In: Carboyhdrates and energy metabolism (Bouiton NA, Baker GB, eds), pp 43-98. Clifton, NJ: Humana.

Lesné S, Koh MT, Kotilinek L, Kayed R, Glabe CG, Yang A, Gallagher M, Ashe $\mathrm{KH}$ (2006) A specific amyloid-beta protein assembly in the brain impairs memory. Nature 440:352-357.

Li WW, Yang R, Guo JC, Ren HM, Zha XL, Cheng JS, Cai DF (2007) Localization of alpha-synuclein to mitochondria within midbrain of mice. Neuroreport 18:1543-1546.

Liu J, Dai Q, Chen J, Durrant D, Freeman A, Liu T, Grossman D, Lee RM (2003) Phospholipid scramblase 3 controls mitochondrial structure, function, and apoptotic response. Mol Cancer Res 1:892-902.

Maroteaux L, Campanelli JT, Scheller RH (1988) Synuclein: a neuronspecific protein localized to the nucleus and presynaptic nerve terminal. J Neurosci 8:2804-2815.

Martin LJ, Pan Y, Price AC, Sterling W, Copeland NG, Jenkins NA, Price DL, Lee MK (2006) Parkinson's disease alpha-synuclein transgenic mice develop neuronal mitochondrial degeneration and cell death. J Neurosci 26:41-50.

McNulty BC, Tripathy A, Young GB, Charlton LM, Orans J, Pielak GJ (2006) Temperature-induced reversible conformational change in the first 100 residues of alpha-synuclein. Protein Sci 15:602-608.

Mori F, Tanji K, Yoshimoto M, Takahashi H, Wakabayashi K (2002) Demonstration of alpha-synuclein immunoreactivity in neuronal and glial cytoplasm in normal human brain tissue using proteinase $\mathrm{K}$ and formic acid pretreatment. Exp Neurol 176:98-104.

Mori F, Nishie M, Kakita A, Yoshimoto M, Takahashi H, Wakabayashi K (2006) Relationship among alpha-synuclein accumulation, dopamine synthesis, and neurodegeneration in Parkinson disease substantia nigra. J Neuropathol Exp Neurol 65:808-815.

Nakamura K, Bindokas VP, Kowlessur D, Elas M, Milstien S, Marks JD, 
Halpern HJ, Kang UJ (2001) Tetrahydrobiopterin scavenges superoxide in dopaminergic neurons. J Biol Chem 276:34402-34407.

Oancea E, Meyer T (1998) Protein kinase C as a molecular machine for decoding calcium and diacylglycerol signals. Cell 95:307-318.

Outeiro TF, Lindquist S (2003) Yeast cells provide insight into alphasynuclein biology and pathobiology. Science 302:1772-1775.

Pagans S, Pedal A, North BJ, Kaehlcke K, Marshall BL, Dorr A, Hetzer-Egger C, Henklein P, Frye R, McBurney MW, Hruby H, Jung M, Verdin E, Ott M (2005) SIRT1 regulates HIV transcription via Tat deacetylation. PLoS Biol 3:e41.

Park J, Lee SB, Lee S, Kim Y, Song S, Kim S, Bae E, Kim J, Shong M, Kim JM, Chung J (2006) Mitochondrial dysfunction in Drosophila PINK1 mutants is complemented by parkin. Nature 441:1157-1161.

Patterson GH, Piston DW, Barisas BG (2000) Forster distances between green fluorescent protein pairs. Anal Biochem 284:438-440.

Perrin RJ, Woods WS, Clayton DF, George JM (2000) Interaction of human alpha-Synuclein and Parkinson's disease variants with phospholipids. Structural analysis using site-directed mutagenesis. J Biol Chem 275:34393-34398.

Perrin RJ, Woods WS, Clayton DF, George JM (2001) Exposure to long chain polyunsaturated fatty acids triggers rapid multimerization of synucleins. J Biol Chem 276:41958-41962.

Pollitt SK, Pallos J, Shao J, Desai UA, Ma AA, Thompson LM, Marsh JL, Diamond MI (2003) A rapid cellular FRET assay of polyglutamine aggregation identifies a novel inhibitor. Neuron 40:685-694.

Polymeropoulos MH, Lavedan C, Leroy E, Ide SE, Dehejia A, Dutra A, Pike B, Root H, Rubenstein J, Boyer R, Stenroos ES, Chandrasekharappa S, Athanassiadou A, Papapetropoulos T, Johnson WG, Lazzarini AM, Duvoisin RC, Di Iorio G, Golbe LI, Nussbaum RL (1997) Mutation in the alphasynuclein gene identified in families with Parkinson's disease. Science 276:2045-2047.

Poskanzer KE, Marek KW, Sweeney ST, Davis GW (2003) Synaptotagmin I is necessary for compensatory synaptic vesicle endocytosis in vivo. Nature 426:559-563.

Purisai MG, McCormack AL, Langston WJ, Johnston LC, Di Monte DA (2005) Alpha-synuclein expression in the substantia nigra of MPTPlesioned non-human primates. Neurobiol Dis 20:898-906.

Rideout HJ, Dietrich P, Savalle M, Dauer WT, Stefanis L (2003) Regulation of alpha-synuclein by bFGF in cultured ventral midbrain dopaminergic neurons. J Neurochem 84:803-813.

Saudou F, Finkbeiner S, Devys D, Greenberg ME (1998) Huntingtin acts in the nucleus to induce apoptosis but death does not correlate with the formation of intranuclear inclusions. Cell 95:55-66.

Schapira AH, Cooper JM, Dexter D, Clark JB, Jenner P, Marsden CD (1990) Mitochondrial complex I deficiency in Parkinson's disease. J Neurochem 54:823-827.

Schechtman D, Craske ML, Kheifets V, Meyer T, Schechtman J, MochlyRosen D (2004) A critical intramolecular interaction for protein kinase Cepsilon translocation. J Biol Chem 279:15831-15840.

Serpell LC, Berriman J, Jakes R, Goedert M, Crowther RA (2000) Fiber diffraction of synthetic alpha-synuclein filaments shows amyloid-like crossbeta conformation. Proc Natl Acad Sci U S A 97:4897-4902.

Shavali S, Brown-Borg HM, Ebadi M, Porter J (2008) Mitochondrial localization of alpha-synuclein protein in alpha-synuclein overexpressing cells. Neurosci Lett 439:125-128.

Shepherd GM, Harris KM (1998) Three-dimensional structure and composition of CA3->CA1 axons in rat hippocampal slices: implications for presynaptic connectivity and compartmentalization. J Neurosci 18:8300-8310.

Siegel RM, Chan FK, Zacharias DA, Swofford R, Holmes KL, Tsien RY, Lenardo MJ (2000) Measurement of molecular interactions in living cells by fluorescence resonance energy transfer between variants of the green fluorescent protein. Sci STKE 2000:PL1.

Singleton AB, Farrer M, Johnson J, Singleton A, Hague S, Kachergus J, Hulihan M, Peuralinna T, Dutra A, Nussbaum R, Lincoln S, Crawley A, Hanson M, Maraganore D, Adler C, Cookson MR, Muenter M, Baptista M, Miller D, Blancato J, Hardy J, Gwinn-Hardy K (2003) alpha-Synuclein locus triplication causes Parkinson's disease. Science 302:841.

Smith WW, Jiang H, Pei Z, Tanaka Y, Morita H, Sawa A, Dawson VL, Dawson TM, Ross CA (2005) Endoplasmic reticulum stress and mitochondrial cell death pathways mediate A53T mutant alpha-synuclein-induced toxicity. Hum Mol Genet 14:3801-3811.

Snapp EL, Hegde RS (2006) Rational design and evaluation of FRET exper- iments to measure protein proximities in cells. In: Current protocols in cell biology, pp 17.19.11-17.19.20. New York: Wiley.

Sperka-Gottlieb CD, Hermetter A, Paltauf F, Daum G (1988) Lipid topology and physical properties of the outer mitochondrial membrane of the yeast, Saccharomyces cerevisiae. Biochim Biophys Acta 946:227-234.

Spillantini MG, Schmidt ML, Lee VM, Trojanowski JQ, Jakes R, Goedert M (1997) Alpha-synuclein in Lewy bodies. Nature 388:839-840.

Stichel CC, Zhu XR, Bader V, Linnartz B, Schmidt S, Lübbert H (2007) Mono- and double-mutant mouse models of Parkinson's disease display severe mitochondrial damage. Hum Mol Genet 16:2377-2393.

Sung YH, Eliezer D (2006) Secondary structure and dynamics of micelle bound beta- and gamma-synuclein. Protein Sci 15:1162-1174.

Susin SA, Larochette N, Geuskens M, Kroemer G (2000) Purification of mitochondria for apoptosis assays. Methods Enzymol 322:205-208.

Tofaris GK, Garcia Reitböck P, Humby T, Lambourne SL, O'Connell M, Ghetti B, Gossage H, Emson PC, Wilkinson LS, Goedert M, Spillantini MG (2006) Pathological changes in dopaminergic nerve cells of the substantia nigra and olfactory bulb in mice transgenic for truncated human alpha-synuclein(1-120): implications for Lewy body disorders. J Neurosci 26:3942-3950.

Uversky VN, Li J, Fink AL (2001a) Evidence for a partially folded intermediate in alpha-synuclein fibril formation. J Biol Chem 276:10737-10744.

Uversky VN, Lee HJ, Li J, Fink AL, Lee SJ (2001b) Stabilization of partially folded conformation during alpha-synuclein oligomerization in both purified and cytosolic preparations. J Biol Chem 276:43495-43498.

Valente EM, Abou-Sleiman PM, Caputo V, Muqit MM, Harvey K, Gispert S, Ali Z, Del Turco D, Bentivoglio AR, Healy DG, Albanese A, Nussbaum R, González-Maldonado R, Deller T, Salvi S, Cortelli P, Gilks WP, Latchman DS, Harvey RJ, Dallapiccola B, Auburger G, Wood NW (2004) Hereditary early-onset Parkinson's disease caused by mutations in PINK1. Science 304:1158-1160.

Volles MJ, Lansbury PT Jr (2007) Relationships between the sequence of alpha-synuclein and its membrane affinity, fibrillization propensity, and yeast toxicity. J Mol Biol 366:1510-1522.

Volles MJ, Lee SJ, Rochet JC, Shtilerman MD, Ding TT, Kessler JC, Lansbury PT Jr (2001) Vesicle permeabilization by protofibrillar alpha-synuclein: implications for the pathogenesis and treatment of Parkinson's disease. Biochemistry 40:7812-7819.

Wang X, Li W, Parra JL, Beugnet A, Proud CG (2003) The C terminus of initiation factor $4 \mathrm{E}$-binding protein 1 contains multiple regulatory features that influence its function and phosphorylation. Mol Cell Biol 23:1546-1557.

Weatherman RV, Chang CY, Clegg NJ, Carroll DC, Day RN, Baxter JD, McDonnell DP, Scanlan TS, Schaufele F (2002) Ligand-selective interactions of ER detected in living cells by fluorescence resonance energy transfer. Mol Endocrinol 16:487-496.

Weinreb PH, Zhen W, Poon AW, Conway KA, Lansbury PT Jr (1996) NACP, a protein implicated in Alzheimer's disease and learning, is natively unfolded. Biochemistry 35:13709-13715.

Willingham S, Outeiro TF, DeVit MJ, Lindquist SL, Muchowski PJ (2003) Yeast genes that enhance the toxicity of a mutant huntingtin fragment or alpha-synuclein. Science 302:1769-1772.

Withers GS, George JM, Banker GA, Clayton DF (1997) Delayed localization of synelfin (synuclein, NACP) to presynaptic terminals in cultured rat hippocampal neurons. Brain Res Dev Brain Res 99:87-94.

Zacharias DA, Violin JD, Newton AC, Tsien RY (2002) Partitioning of lipidmodified monomeric GFPs into membrane microdomains of live cells. Science 296:913-916.

Zarranz JJ, Alegre J, Gómez-Esteban JC, Lezcano E, Ros R, Ampuero I, Vidal L, Hoenicka J, Rodriguez O, Atarés B, Llorens V, Gomez Tortosa E, del Ser T, Muñoz DG, de Yebenes JG (2004) The new mutation, E46K, of alphasynuclein causes Parkinson and Lewy body dementia. Ann Neurol 55:164-173.

Zhang L, Zhang C, Zhu Y, Cai Q, Chan P, Uéda K, Yu S, Yang H (2008) Semi-quantitative analysis of alpha-synuclein in subcellular pools of rat brain neurons: an immunogold electron microscopic study using a C-terminal specific monoclonal antibody. Brain Res. Advance online publication. Retrieved November 4, 2008. doi: 10.1016/j.brainres.2008.08.067.

Zhu M, Fink AL (2003) Lipid binding inhibits alpha-synuclein fibril formation. J Biol Chem 278:16873-16877. 